\title{
Tidal and seasonal effects on the short-term temporal patterns of bacteria, microphytobenthos and exopolymers in natural intertidal biofilms (Brouage, France)
}

Orvain Francis ${ }^{(1)}$, De Crignis Margot ${ }^{(1,2)}$, Guizien Katell ${ }^{(3)}$, Lefebvre Sébastien ${ }^{(4)}$, Mallet Clarisse $^{(5)}$, Takahashi Eri ${ }^{(1)}$, Dupuy Christine ${ }^{(2)}$.

(1): Université de Caen Basse-Normandie, UMR BOREA (MNHN, UPMC, UCBN, CNRS7208, IRD-207), Esplanade de la Paix, 14032 Caen, France

(2) UMR 7266 CNRS - Laboratoire LIENSs, Université de La Rochelle, 2 rue Olympe de Gouges, 17000 La Rochelle cedex, France.

(3) CNRS, FRE3350, LECOB, Observatoire Océanologique, 66651, Banyuls/mer, France

(4) Université de Lille1 Sciences et Technologies, CNRS, UMR 8187 LOG «Laboratoire d'Océanologie et de Géosciences », Station Marine de Wimereux, 28 av. Foch, 62930 Wimereux, France

(6) Laboratoire Microorganismes: Génome et Environnement, UMR 6023 CNRS-Université de Clermont-Ferrand II, 24 avenue des Landais, 63177 Aubière Cedex, France

* Corresponding author: francis.orvain@unicaen.fr

\begin{abstract}
Relationships between bacteria, microphytobenthos and extracellular polymeric substances (EPS) that make up microbial biofilms over bare mudflats were investigated at an hourly frequency during two 14-day spring-neap cycles in winter and summer 2008. Bacterial abundance and total chl $a$ concentration were lower in summer $\left(0.78 \times 10^{8} \pm\right.$ SD $0.39 \times 10^{8}$ cell. $\mathrm{m}^{-}$
\end{abstract}


${ }^{2}$ and $59.0 \pm$ SD $\left.10.42 \mathrm{mg}_{\text {chla. }} \mathrm{m}^{-2}\right)$ than in winter $\left(3.7 \times 10^{8} \pm \mathrm{SD} 1.9 \times 10^{8}\right.$ cell. $\mathrm{m}^{-2}$ and $106.64 \pm \mathrm{SD}$ $11.29 \mathrm{mg}_{\text {chla. }} \mathrm{m}^{-2}$ ), coinciding with a high abundance of the gastropod Peringia ulvae in summer, which subsequently impacted $1^{\text {st }}$-cm $\operatorname{chl} a$ concentration by intense grazing. Bound and colloidal EPS carbohydrate temporal patterns were similar in winter $(5.71 \pm$ SD 3.95 and $4.67 \pm$ SD $3.45 \mu \mathrm{g} \cdot \mathrm{g}^{-1}$, respectively) but were different in summer $(14.9 \pm \mathrm{SD} 4.05$ and $5.60 \pm \mathrm{SD} 4.50$ $\mu \mathrm{g} \cdot \mathrm{g}^{-1}$, respectively). Carbohydrate colloidal EPS appeared to be related to light and salinity, while $1^{\text {st }}$-mm chl $a$ concentration was negatively affected by strong salinities and predation pressure by $P$. ulvae. The fluctuations of colloidal carbohydrates were remarkably similar in the two seasons with peaks just after spring tides when the highest irradiance was received by microphytobenthic cells. Apparently, colloidal EPS carbohydrates can protect cells against the high salinity values ranging from 32.3 to 50.4 PSU. The presence of bound EPS carbohydrates may be linked to sediment colonization and resistance of biofilm activity. Proteins in EPS were absent in winter and represented a small proportion in summer (10\%), but they appeared to be a good indicator of potential synergistic effects between MPB and bacteria in summer. Conversely, bound EPS carbohydrates reached high levels in winter, while the number of bacteria decreased simultaneously, suggesting a negative effect on bacterial growth in absence of proteins in EPS. There was a lower proportion (31\%) of low molecular weight EPS in summer than in winter $(83 \%)$, possibly in relation to desiccation.

\section{KEY WORDS}

Extracellular Polymeric Substances (EPS), Protein, Benthic diatoms, Bacteria, Biofilm, Intertidal mudflat. 


\section{INTRODUCTION}

Intertidal mudflats cover large surface areas in macrotidal estuaries at low tide and they are among the most productive marine zones in the world (Admiraal et al., 1984; Mann , 1982). This high productivity is partly due to the formation of a transient microphytobenthic biofilm that could develop at the surface during daily tidal exposure periods (Blanchard et al., 2001; Underwood and Paterson, 2003). In addition to surficial sediment and interstitial pore water, these biofilms are composed of 1) microphytobenthos (MPB) mainly comprising epipelic diatoms i.e. Heterokontophyta Bacillariophyta (Admiraal et al., 1984; MacIntyre and Cullen, 1996; Underwood and Kronkamp, 1999), 2) prokaryotes, mainly composed of bacteria (van Duyl et al., 2000) and 3) extracellular polymeric substances (EPS) secreted by both microphytobenthos and prokaryotes (Decho, 1990; Decho, 2000; van Duyl et al., 2000). Although most EPS production has been ascribed to diatoms (Underwood and Paterson, 2003), it has been shown that these EPS are not only composed of carbohydrates but also uronic acids and glycoproteins and other minor compounds (Decho, 1990; Flemming and Wingender, 2002; Giroldo et al., 2005)

The main EPS fractions have been distinguished on the basis of their metabolic secretion pathways, size or chemical composition (Abdullahi et al., 2006; de Brouwer and Stal, 2001; Hanlon et al., 2006; Underwood and Paterson, 2003). Excretion of these fractions varies with the physiological status of the microalgae and/or influence of abiotic factors. To date, the different methods used to extract the EPS fractions involved numerous contaminations by internal components, resulting in different characterization of EPS composition and structure, depending on environmental conditions as well as operational methodology (Chiovitti et al., 2004; Takahashi et al., 2009). However, EPS can be classified in two main fractions: colloidal EPS that are soluble in saline water and excreted in the vicinity of cells, and bound EPS that are tightly attached to the algal cell wall. Bound and colloidal EPS are composed of low 
molecular weight (LMW, $<1 \mathrm{kDa})$ and high molecular weight (HMW, $>1 \mathrm{kDa})$ carbohydrates (Amon and Benner, 1996). Several diatom wall-associated protein and glycoprotein families have been also characterized such as frustulins in bound EPS (Chiovitti et al., 2003). Because they are less abundant, the role of proteins in EPS and MPB biofilms have less been studied than carbohydrate in literature. Nevertheless, recent investigations show the key-role in the biofilm properties, mutualism between microorganisms and adherence (Gerbersdorf et al., 2008 ; Lubarsky et al., 2010). The first objective of the present study was to improve knowledge on EPS secretion and potential properties on the field after recent protocol optimization (extraction with dowex resin) by focusing on protein constituents as well as carbohydrates.

The natural rhythmicity of production patterns of EPS by diatoms are extensively described in the literature (de Brouwer and Stal, 2001; Hanlon et al., 2006; Orvain et al., 2003; Perkins et al., 2003; Smith and Underwood, 1998) and have been associated with: 1) migration through the sediment (Hoagland et al., 1993) in response to tidal and endogenous rhythms (Smith and Underwood, 1998); 2) physiological responses to environmental stress and metabolic overflow (Orvain et al., 2003; Perkins et al., 2001; Staats et al., 2000; Underwood and Paterson, 2003). There is a general consensus over the different synthesis pathways of some fractions of diatom EPS and the composition and production of EPS vary with environmental factors and physiological functions (Decho, 1990; Hoagland et al., 1993; Underwood and Paterson, 2003). As far as sediment properties are concerned, colloidal EPS can help limit desiccation by maintaining high pore water content (Orvain et al., 2003) while bound EPS can also have other functions such as stabilizing sediment grains and reducing erodibility (de Brouwer et al., 2005 ; Gerbersdorf et al., 2008 ; Lubarsky et al., 2010; Yallop et al., 2000) but also serving to protect benthic diatoms for cell-cell communication and protection against the hydrolases of attached bacteria (Flemming and Wingender, 2010; Smith et al., 1995). The 
second objective was to better understand the EPS production by MPB in a wide range of natural situations in terms of light and salinity changes.

EPS could represent a substantial source of labile material that can be used by heterotrophic bacteria (Hanlon et al., 2006; Hofmann et al., 2009; Middelburg et al., 2000; Oakes et al., 2010). On intertidal mudflats, heterotrophic bacteria have both high production rates (Cammen, 1991; Hamels et al., 2001) and high abundances (Schmidt et al., 1998). The ability of heterotrophic bacteria to assimilate EPS may depend on which fractions are considered (Middelburg et al., 2000; Hanlon et al., 2006; Haynes et al., 2007 ; Oakes et al., 2010). Among the various monomers than compose the carbohydrate fraction of EPS matrix, glucose is clearly more easily transferred to bacteria than more refractory component such as deoxy sugars like fucose or rhamnose (Giroldo et al., 2003; Hofmann et al., 2009; Oakes et al., 2010). However, interactions between diatoms and bacteria are not limited to the simple transfer of carbon photosynthetically assimilated by diatoms to bacterial communities (Bellinger et al., 2009). Heterotrophic bacterial growth is also enhanced by the decomposition of dead diatoms (Walksman et al., 1937), after which labile internal compounds are released. We aimed at understanding how the quantity of secreted EPS on the field by MPB may control bacteria development in the biofilm by considering trophic pathways but also other potential interaction between bacteria and MPB (like competition for nutrients or negative cell/cell interaction).We thus investigated the short-term changes in the carbohydrate and protein contents of EPS fractions in transient biofilm during exposure periods. The aim of the present study was to explore the seasonal and tidal effects on the relationship between bacteria, exopolymers and MPB as a function of a wide range of ecological factors. These 3 variables were studied during neap-spring-tide cycles in two contrasting seasons (February and July in 2008).

\section{METHODS}




\section{Study site and sampling method}

The study was conducted from February 16 to 24 (winter) and from July 13 to 26 (summer) at the Brouage mudflat $\left(45^{\circ} 54^{\prime} 50^{\prime \prime} \mathrm{N}, 01^{\circ} 05^{\prime} 25^{\prime \prime} \mathrm{W}\right)$, in the Marennes-Oléron Bay (MOB), an intertidal temperate bare mudflat in Charente-Maritime on the Atlantic coast of France (Fig 1A). This bay is characterized by semi-diurnal tides and a macrotidal regime with fluctuations in tidal range ( $~ 6 \mathrm{~m}$ during spring tides). In MOB, the longest emersion periods during spring tides are centered on solar noon (Fig. 2A and 2B). To enable relevant comparisons between the two seasons sampled, the dates were labeled in such a way that the maximum tidal amplitudes were phase locked (Fig. 2A). Summer sampling covered the period from day 1 to day 14 , winter sampling covered the period from day 3 to day 11 , with day 9 corresponding to the highest tidal amplitude in the 2 seasons (the longest diurnal exposure time, i.e. on February 22 and July 21).

All samples were taken in a 20x20 m square experimental study area (one per season) delimited by two perpendicular lines of wood stakes spaced $2 \mathrm{~m}$ apart. The study area was covered by system of cross-shore ridges and runnels (Fig. 1B). The coordinates of subunits (2 $\times 2 \mathrm{~m}$ squares, Fig. 1B) were defined by the wood stakes. Each day, three replicate squares were chosen randomly according to the sampling design described in a previous field study (Orvain et al., 2012). In these squares, surficial sediment was sampled hourly from the beginning ( 0 hour after area emersion) to the end of emersion (3 hours after area emersion), leading to four sampling times during every emersion periods. Five cores $(15 \mathrm{~cm}$ in diameter $)$ were taken from each square on consolidated ridges, of which the $1^{\text {st }}$ surficial $\mathrm{cm}(\sim 200 \mathrm{~mL})$ was cut and pooled. All samples were immediately brought back to the beach using a hovercraft. After being cautiously homogenized, the volume of mud was then determined by using cut syringes and split into flasks before further analysis of chl $a$ concentration, bacterial abundance, and EPS contents. 
Every day, 1 hour after beginning of emersion time, 3 additional cores $(15 \mathrm{~cm}$ in diameter) were taken in each square in order to assess Peringia ulvae (gastropods) densities. The upper two centimeters of the three cores were pooled. Mud samples were sieved $(500 \mu \mathrm{m}$ net mesh) and stored frozen $\left(-20^{\circ} \mathrm{C}\right)$. Irradiance $\left(\mu \mathrm{mol}\right.$ photons $\left.\mathrm{m}^{-2} \mathrm{~s}^{-1}\right)$ at the mudflat surface during the survey was measured with a PAR probe at the site (LICOR in February 2008 and MDS ALEC in July 2008). Meteorological data (wind speed, air temperature, rainfall, irradiance) were measured at La Rochelle airport by METEO FRANCE.

\section{Estimating the abundance of heterotrophic bacteria}

To estimate the number of bacterial cells, $5 \mathrm{~mL}$ of homogenized mud were placed in flasks containing $5 \mathrm{~mL}$ of $0.2 \mu \mathrm{m}$ filtered formaldehyde ( $2 \%$ final concentration) and stored at $4{ }^{\circ} \mathrm{C}$ until analysis. To detach particle-associated bacteria, $1 \mathrm{~mL}$ samples (1/2 mudformaldehyde) were used to make successive dilutions of $1 / 2,1 / 10$ then $1 / 100$ with $0.2 \mu \mathrm{m}$ filtered pyrophosphate (0.01 M final concentration). Diluted samples were incubated for a minimum of $30 \mathrm{~min}$ at $4{ }^{\circ} \mathrm{C}$, then ultrasonicated $(60 \mathrm{~W}, 30 \mathrm{sec})$. Bacteria were stained with 4,6diamidino-2-phenylindole dihydrochloride (DAPI, $2500 \mu \mathrm{g} \mathrm{L}^{-1}$ final concentration) for $15 \mathrm{~min}$ in the dark at $4{ }^{\circ} \mathrm{C}$ and filtered onto $0.2 \mu \mathrm{m}$ Nucleopore black filters (Porter and Feig, 1980). Bacterial cells were observed under an epifluorescence UV microscope (x1000, Axioskop 2 mot plus - Zeiss). Cells from at least 15 fields were counted.

\section{Analyses of pigment concentration}

Approximately $80 \mathrm{~mL}$ of homogenized mud were immediately stored frozen $\left(-20{ }^{\circ} \mathrm{C}\right)$ after sampling. Pigments of $\sim 200 \mathrm{mg}$ of freeze-dried sediment from the upper $\mathrm{cm}$ of the sediment were extracted in $10 \mathrm{~mL}$ of $90 \%$ acetone by continuously rotating $(12 \mathrm{rpm})$ the samples for $18 \mathrm{~h}$ in the dark at $4^{\circ} \mathrm{C}$. After centrifugation $\left(4{ }^{\circ} \mathrm{C}, 2000 \mathrm{~g}, 5 \mathrm{~min}\right)$, fluorescence of 
the supernatant was measured using a Fluorometer Turner TD-700 before and after acidification $(10 \mu \mathrm{L} \mathrm{HCl} 0.3 \mathrm{M}$ for $1 \mathrm{~mL}$ acetone). Chlorophyll $a$ (chl $a)$ and phaeopigments were then measured using the fluorometric method (Lorenzen 1966) and converted in $\mathrm{mg} . \mathrm{m}^{-2}$ (i.e. concentration) by using volumetric mass of fresh sediment.

\section{Biofilm fluorescence measurement $\left(F_{0}\right)$ and $1^{\text {st }} \mathbf{m m}$ chl $a$ concentration}

The minimal fluorescence of benthic microalgae $\left(\mathrm{F}_{0}\right)$ was used as a proxy of MPB biomass in the biofilm directly on the field and measured using a PAM (Pulse Amplitude Modulation) fluorimeter including a PAM-control unit and a WATER-EDF-universal emitter detector unit (Walz, Effeltrich, Germany). The PAM fiber optic probe was placed carefully at $2 \mathrm{~mm}$ of the MPB biofilms using a $4 \mathrm{~cm}$ diameter ring isolating the sample from natural light. It was maintained using a burette holder fixed on a base buried in the first $20 \mathrm{~cm}$ of sediment. $\mathrm{F}_{0}$ was estimated after dark acclimation of 5 minutes. Three replicates were chosen randomly within an area of $1 \mathrm{~m}^{2}$.

$\mathrm{F}_{0}$ were converted into chl $a$ concentration in the biofilm after a calibration based on chl $a$ microprofiles. One square meter surface was selected where depth microscale profiles of chl $a$ biomass were established. Three minicores (top $5 \mathrm{~mm}$ of surface sediment and $1.2 \mathrm{~cm}$ in diameter) were taken after fluorescence surface analysis and immediately frozen with liquid nitrogen haze on the field. Once frozen, they were plunged in the liquid $\mathrm{N}_{2}$ and brought back to the lab where they were preserved at $-80^{\circ} \mathrm{C}$ and then sliced (at each $200 \mu \mathrm{m}$ interval depth) using a cryolanding techniques $\left(-15^{\circ} \mathrm{C}\right)$. Each sliced section of the sediment was placed in preweighed Eppendorf tube and freeze-dried and the dry mass was measured before pigment analysis (similar than for pigment analyses from uppermost centimeter). Dry density measurements of the sediment were used to convert chl $a$ content $\left(\mu \mathrm{g} \cdot \mathrm{gDW}^{-1}\right)$ to $\operatorname{chl} a$ concentration (mg chl $\left.a . \mathrm{m}^{-2}\right)$. 
$\mathrm{F}_{0}$ was calculated from PAM data during the 2 campaigns and was correlated to chl $a$ concentration $\left(\mathrm{mg} \mathrm{m}^{-2}\right)$ at different integration depth from microscale vertical profile (from 200 $\mu \mathrm{m}$ to $5 \mathrm{~mm}$ ). The chl $a$ concentration at a depth of $1 \mathrm{~mm}$ was estimated and converted into $\mathrm{mg}$ chl $a \mathrm{~m}^{-2}$ using an estimation of sediment bulk density (mg DW $\mathrm{L}^{-1}$ ). A linear equation (see Appendix) was used to extrapolate the whole series of $\mathrm{F}_{0}$ values in chl $a$ concentration $(\mathrm{mg}$ chl $\left.a \mathrm{~m}^{-2}\right)$.

\section{Analyses of extracellular polymeric substances (EPS)}

EPS were extracted from $5 \mathrm{~mL}$ of fresh sediment and placed in $15 \mathrm{~mL}$ centrifugation tubes in $5 \mathrm{~mL}$ of $0.2 \mu \mathrm{m}$ filtered and sterilized artificial sea water (ASW). Fresh sediments were used (instead of freeze-dried sediments) to avoid any cell disruption and contamination of EPS extracts by storage chrysolaminan (Chiovitti et al., 2004; Takahashi et al., 2009). After 1h of incubation in artificial seawater, vortexing, tubes were centrifuged at $4{ }^{\circ} \mathrm{C}, 3000 \mathrm{~g}$ for 10 minutes. Supernatants containing the colloidal fraction, were collected in a new centrifugation tube and stored frozen $\left(-20^{\circ} \mathrm{C}\right)$ until further analysis.

In addition to colloidal EPS, we have chosen to study the specific temporal pattern of bound EPS extracted with a cationic resin (Dowex). Even if this procedure is recognized to extract only small proportion of the total bulk of EPS (Pierre et al., 2012), they can be strictly considered as EPS, contrary to extracts with distilled water, whose internal compounds make up the majority of the sample (Takahashi et al., 2009). The aim was to focus on an EPS fraction that can be considered as a pure extract of EPS, after optimization of the extraction procedure (Takahashi et al., 2009) to better evaluate their quality and their specific temporal pattern. Bound EPS were thus extracted from pellets by adding $\sim 1 \mathrm{~g}$ of cation exchange resin (Dowex Marathon $\mathrm{C}, \mathrm{Na}+$; Sigma-Aldrich) and $5 \mathrm{~mL}$ ASW. After resuspension, tubes were gently agitated for $1 \mathrm{~h}$ at $4{ }^{\circ} \mathrm{C}$ in the dark and then centrifuged $\left(4{ }^{\circ} \mathrm{C}, 3000 \mathrm{~g}, 10 \mathrm{~min}\right)$. The supernatants 
were collected and kept frozen $\left(-20^{\circ} \mathrm{C}\right)$ for further analysis of bound EPS. For each EPS fraction (colloidal and bound), low and high molecular weight EPS (LMW and HMW) were extracted by incubating the samples in ethanol (70\% final concentration) for 16 hours at $-20{ }^{\circ} \mathrm{C}$. Samples were centrifuged $\left(4^{\circ} \mathrm{C}, 4000 \mathrm{~g}, 30 \mathrm{~min}\right)$. LMW EPS were collected in the supernatant and HMW EPS were collected in the pellet. The supernatant was decanted into a new tube and both the supernatant and the pellet were dried at $60{ }^{\circ} \mathrm{C}$ in a dry bath under air flow (from 6 to $48 \mathrm{~h}$ depending on the fraction). The dried samples were resuspended in $5 \mathrm{~mL}$ distilled water and stored at $-20{ }^{\circ} \mathrm{C}$ for carbohydrate and protein quantification.

For each fraction, $1 \mathrm{~mL}$ aliquots were removed to measure carbohydrate contents using sulfuric acid and phenol (Dubois et al., 1956 ) with glucose as a standard. Additional $1 \mathrm{~mL}$ aliquots were used to estimate protein contents with the Bradford assay (Bradford, 1976) using bovine serum albumin (BSA) from Sigma-Aldrich as standard. Absorbance was read on multiwall plates (96) for a wavelength of $600 \mathrm{~nm}$ using a bioluminometer (Mithras LB 940 Berthold Technologies). Small aliquots of $160 \mu 1$ of sample (and BSA standards for standard curves) were taken and mixed with $40 \mu \mathrm{L}$ of Bradford assay reagent (Bio-Rad).

Pore water was separated from $300 \mathrm{~mL}$ of fresh sediment by centrifugation $\left(4{ }^{\circ} \mathrm{C}, 3000\right.$ g, $15 \mathrm{~min}$ ). Interstitial water was filtered through GF/C filters and salinity was then read by refractometer. After homogenization, $\sim 5 \mathrm{~mL}$ of fixed sediment was added to water circulating in a granulometer Malvern Mastersizer 2000 laser particle size analyzer. Sediment pore water content (in \%) was calculated using the difference in weight between fresh and dried sediment $\left(72 \mathrm{~h}, 60^{\circ} \mathrm{C}\right)$.

\section{Statistical tests}

In order to test whether differences in means between the two seasons were significant $(\alpha<0.05)$, T-Tests were performed using ExcelStat. To evaluate the spatio-temporal variations 
of each response variable (Bacterial abundance, Chl $a$ concentration, EPS contents), Mantel analyses are the best tests (i) to detect the presence of inherent spatial autocorrelation and (ii) to separate the effects of temporal variation (i.e. between-day and within-day) from spatial effects. These non-parametric tests are most appropriate when data are spatially auto-correlated (Legendre and Legendre, 1998; Fortin and Gurevitch, 2001). The space-time clustering procedure of Mantel (Mantel correlation RM and partial Mantel correlation $\mathrm{RM}^{*}$ ) was performed to relate a matrix of Euclidian geographic distance among sampling sites and 3 matrices of temporal distance (hour and date, separately) with a matrix of distance between values of response variables in a generalized regression approach (Orvain et al., 2012). In the present study, 2000 iterations were run using home-made programs coded in MATLAB 2008B.

Correlations were tested to calculate the Pearson's correlation coefficient R. These correlation tests were run on winter results, summer datasets separately to explore the whole field of correlation between bacterial abundance, $1^{\text {st }} \mathrm{cm}$ chl $a$ concentration, $1^{\text {st }} \mathrm{mm} \operatorname{chl} a$ concentration with other environmental variables. Multiple regression approach was also performed to select explanatory variables among all ecological parameters that could primarily explain the variation of response variables (Bacterial abundance, $1^{\text {st }} \mathrm{cm}$ chl $a$ concentration, $1^{\text {st }}$ mm chl $a$ concentration, EPS contents). A step-by-step approach was tested to search for the best regression model upon separate datasets (MINITAB release 15).

\section{RESULTS}

\section{Temporal pattern of environmental factors}

Irradiance at the mud surface (Fig. 2B) was significantly higher in summer than in winter $(\mathrm{T}=13.4, \mathrm{P}<0.0001)$, with low values recorded on the rainy day (day 13 of the summer survey). Due to specific phase-locking in tidal harmonics in one neap-spring tidal cycle in MOB, low tide was at midday during spring tides while high tide was at midday during neap 
tides. As a consequence, during spring tides (Fig. 2A), the maximum emerged surface area of the mudflat coincided with the maximum supply of sunlight energy. The effect of transient clouds clearly affected the winter irradiance signal (Fig. 2B).

Median grain size was similar in the two seasons and variation remained negligible during each survey (mean values of $10.2 \mu \mathrm{m}$ in winter and 11.0 in summer, data not shown). Pore water content fluctuated from $55 \%$ to $70 \%$ in winter with significant differences between days $\left(\mathrm{F}_{8,17}=3.55 ; \mathrm{P}<0.001\right)$. The average pore water content was $61.6 \pm \mathrm{SD} 2.7 \%$ in winter (Fig. 2D) and pore water content was lower in summer $(\mathrm{T}=-25.7, \mathrm{P}<0.0001)$ with the average value of $52.2 \%$. There was little variation between days during summer but values were lower during spring tide and they systematically decreased during emersion due to evaporation processes (except on day 1 in summer, Fig. 2D).

Salinity (S\%o) fluctuated between 32 and 35\% in winter, except on day 7, when salinity decreased to $29 \%$ due to rainfall (this was the only rainfall event during the winter survey, Fig. 3F). Salinity values were significantly higher in summer than in winter (Fig. $2 \mathrm{C}, \mathrm{T}=-23.2, \mathrm{P}<$ 0.0001). In summer, there was a succession of small step-by-step increases in salinity during emersion periods and these increases got progressively larger from one day to the next during the prolonged period of high irradiance when low tide occurred between 9 AM and 7 PM in summer (Fig. 2C). Salinity fell drastically on day 13 due to a heavy but brief rainfall event and irradiance was tempered by clouds throughout the exposure period, associated with a simultaneous drop in temperature. The correlation between water content and salinity was not significant in winter $(\mathrm{R}=0.08 ; \mathrm{P}=0.40)$, but negative in summer $(\mathrm{r}=-0.38, \mathrm{P}<0.001)$, which is consistent with increased evaporation/desiccation during high temperature and windy periods (Fig. 2E and 2F). The effect of wind stress also explains part of evaporation, since there was a positive correlation between salinity and wind speed observed in summer $(\mathrm{R}=0.60 ; \mathrm{P}<0.001)$ but not in winter $(\mathrm{R}=0.02 ; \mathrm{P}=0.85)$. 
Density of the gastropod Peringia ulvae was high both in summer and winter (Fig. 2G). Summer snail density values $\left(18,000\right.$ ind $\mathrm{m}^{-2}$ on average $)$ were higher than that of the winter $\left(5,000\right.$ ind. $\mathrm{m}^{-2}$ on average, $\left.\mathrm{T}=17.9, \mathrm{P}<0.0001\right)$ and the temporal pattern of these two periods were variable between days, especially in summer. There was a clear increase of snail density during the second period of the winter survey, while snail density varied at a higher frequency in summer with no particular trend.

\section{Temporal pattern of microphytobenthic biomass}

Chl $a$ concentration in the $1^{\text {st }} \mathrm{cm}($ Fig. $3 \mathrm{~A})$ were higher in winter than in summer $(\mathrm{T}=-$ $34.4, \mathrm{P}<0.0001$ ) with a mean of $106.64 \pm \mathrm{SD} 11.29 \mathrm{mg} \mathrm{m}^{-2}$ in winter versus $59.0 \pm \mathrm{SD} 10.42$ $\mathrm{mg} \mathrm{m}^{-2}$ in summer. There was only small variability in summer chl $a$ concentration with minimum values observed on day 8 (i.e. one day before spring tide) during the two surveys (Fig. 3A). Even if no significant effects of hour factor were observed between the samples of chl $a$ concentration between the two seasons (Table 1), differences were significant between dates during the two surveys (even when other effects were held constant). In summer, a small increase occurred after the spring tide, with maximum values obtained on day 11 (two days after the spring tide). Because of this 2-day delay and presumably because of negative effects by tidal amplitude on MPB biomass like the physical constraint and erosion caused by tidal currents, a negative correlation between the tidal amplitude and chl $a$ value was observed in summer (Table 2). Chl a concentrations were also negatively correlated with gastropod abundance during the summer survey, when Peringia ulvae abundances were the highest (see statistics in Table 2). In winter, there was also a significant variation of chl $a$ concentration as a function of date (Table 2), but there was no significant correlation found between the latter variable and ecological factors except pore water content (Table 2). 
There were significant spatial effects on chl $a$ concentration in winter and in summer. Even though the total $1^{\text {st }} \mathrm{cm}$ chl $a$ concentration were different between the seasons $(\mathrm{T}=-34.4$ ; $\mathrm{P}<0.001)$, the signal of chl $a$ concentration within $1^{\text {st }}$ top mm were low in summer and decreased during the first three days and values remained low during the 11 subsequent days (Fig. 3C). In winter, values were also low at the beginning of the survey but chl $a$ concentration in the $1^{\text {st }} \mathrm{mm}$ rapidly increased between day 5 and 8 (except a drop on day 7) and then rapidly decreased on day 9 to remain stable at low values during the last 5 days (Fig. 3C). The seasonal difference was significant $(\mathrm{T}=7.35 ; \mathrm{P}<0.001)$. There was no correlation found between chl $a$ concentration in the $1^{\text {st }} \mathrm{cm}$ for winter or summer (Table $2, \mathrm{R}=0.03$ and $\mathrm{R}=0.05 ; \mathrm{P}=0.84$ and $\mathrm{P}=0.52$, respectively). In spite of a global resemblance between the signals of bacterial abundance and $1^{\text {st }} \mathrm{mm} \operatorname{chl} a$ concentration (Fig. 3B and 3C), detected by a correlation $(\mathrm{R}=0.55$, $\mathrm{P}<0.001)$ when the 2 datasets were pooled, there was no significant correlation found when datasets were separated (Table 2).The signal of $1^{\text {st }} \mathrm{mm}$ chl $a$ concentration was clearly affected by surface processes such as grazing by snails in winter (with a negative correlation with Peringia ulvae density; $\mathrm{R}=-0.31 ; \mathrm{P}<0.05)$ in winter or light stress as shown by the negative correlation with irradiance in summer $(\mathrm{R}=-0.435 ; \mathrm{P}<0.001)$, along with other associated parameters like temperature, tidal amplitude and salinity. In summer, the snail density was always very high (along with high spatial variability revealed by bar errors) and the chl $a$ concentration in the $1^{\text {st }} \mathrm{mm}$ remained low during the 15 days of the survey (Fig.3C).

\section{Temporal pattern of bacteria}

Bacterial cells were significantly less abundant in summer than in winter $(T=-12.3, P$ $<0.0001)$. The differences between summer and winter were exacerbated during spring tides (days 6 to 12). The bacterial abundance and chl $a$ concentration from the $1^{\text {st }} \mathrm{cm}$ were significantly and positively correlated in summer (Table 2), while no significant correlation 
were observed in winter. In winter, the mean bacterial abundance measured in the top $\mathrm{cm}$ was $3.710^{8} \pm \mathrm{SD} 1.910^{8}$ cell $\mathrm{m}^{-2}$ (Fig. 3B). Bacterial abundance increased every day during the first six days, after which it decreased progressively until the end of the winter survey. In winter, there were significant differences between dates (Table 1). Within-day variability of the bacterial abundances was also very high and significant in summer (Table 1). The hourly variation of bacterial abundance was significant in both seasons but, in winter, this effect was not significant when the space factor was held constant (Table 1). In summer, bacterial abundances varied more than one order of magnitude, i.e. from $2.5 \times 10^{7}$ and $2.9 \times 10^{8}$ cell. $\mathrm{m}^{-2}$ (Fig. 3B) with small but significant variations between days (Table 1). Bacterial abundances were significantly affected by spatial distances at the 2 seasons (Table 1). Spatial variability was higher than between-day variability before day 5 and after day 9 , while a gradual decrease in both mean and spatial variability was observed between day 5 and day 9 . Chl $a$ value $\left(1^{\text {st }} \mathrm{cm}\right)$ and bacterial abundance were positively correlated in summer. Temperature did not explain the variations of bacterial abundance, since there were no apparent correlation (Table 2).

\section{$\underline{\text { Extracellular Polymeric Substances }}$}

Proportion of protein and carbohydrate within each EPS fraction varied with the season (Fig. 4). Proteins were completely absent from EPS in winter, but present at a small proportion in summer ( $10 \%$ of total HMW EPS). In winter, there was a similar proportion of carbohydrate in colloidal and bound EPS fractions (47\% versus 53\%). LMW fraction was in higher proportion (83\%) than HMW compounds in carbohydrates, in winter. In summer, there was more HMW than LMW extracts (69 versus $31 \%$ ) and the equilibrium between bound EPS and colloidal EPS also shifted to a dominance of bound EPS for both carbohydrates and proteins (61\%). In contrast, LMW carbohydrates (colloidal, Fig. 5B and bound, Fig. 5D) showed higher 
values in winter than in summer $(\mathrm{T}=-12.9, \mathrm{P}<0.0001$ for colloidal $\mathrm{EPS}, \mathrm{T}=-18.6, \mathrm{P}<0.0001$ for bound EPS).

During the winter survey, there were positive and significant correlation between the four EPS carbohydrate contents $(\mathrm{P}<0.05)$ except between colloidal HMW and LMW fractions (Fig. 5A and 5B). Colloidal and bound HMW carbohydrates (Fig. 5A and 5C) were significantly higher in summer than in winter $(\mathrm{T}=6.89, \mathrm{P}<0.0001$ and $\mathrm{T}=13.7, \mathrm{P}<0.0001$, respectively). Bound HMW proteins were not correlated to any other EPS (P > 0.05), while colloidal HMW proteins were negatively correlated to bound LMW carbohydrates $(\mathrm{P}<0.05)$.

In summer, the situation was quite different since there was no positive correlation found between the 4 fractions. On the contrary, carbohydrate contents of bound HMW fraction were negatively correlated with those of colloidal HMW extract, suggesting opposite metabolic pathways and/or their trophic linkage in summer $(\mathrm{R}=-0.30, \mathrm{P}<0.001)$. On the other hand, there was a positive correlation between bound and colloidal LMW carbohydrates $(\mathrm{R}=0.40, \mathrm{P}$ $<0.001)$. Bound and colloidal HMW proteins were positively correlated in summer $(\mathrm{R}=0.70$ ; $\mathrm{P}<0.001)$. Colloidal HMW proteins were also positively correlated to all other fractions (P $<0.05)$ except to the bound HMW carbohydrates, for which the correlation was negative $(\mathrm{R}=$ $-0.40 ; \mathrm{P}<0.001)$. Similar findings were obtained for bound proteins.

Colloidal HMW carbohydrate temporal pattern were remarkably similar in summer and winter with a pronounced increase on day 8 (Fig. 5A). This result reflects the prevailing influence of variations in exposure to daylight and irradiance by benthic diatoms during one neap-spring tidal cycle.

\section{$\underline{\text { Temporal pattern of carbohydrates in EPS: winter survey }}$}

There were no significant differences between subsequent hours during exposure periods (i.e. hour effets) for the 4 EPS carbohydrates (Table 1). In winter, bound fractions were 
affected by spatial heterogeneity, when temporal effects were held constant, but not the colloidal fractions (Table 1). For HMW bound fraction, there was also a significant effect of the day factor (Table 1) with a decrease between day 2 and 5 and a gradual increase up to day 10 and a decrease after (Fig. 5C). All EPS carbohydrates were affected by day factor in winter (when hour effects were held constant), except the colloidal LMW fraction (Table 1).

Carbohydrate content from the HMW colloidal fraction first decreased until day 5 (in relation to the concomitant decrease in $1^{\text {st }} \mathrm{cm}$ chl $a$ concentration), then significantly increased until day 8 before becoming more unstable (according to standard deviation and rapid changes). Multiple regression analysis revealed the prone effect of snail density and $1^{\text {st }} \mathrm{mm} \operatorname{chl} a$ concentration on carbohydrate content for colloidal HMW carbohydrates (Table 3). Bound EPS showed a continuous increasing pattern, with lower standard deviation. There was a clear decrease during the first five days followed by a gradual increase until day 10 , with the maximal value and a subsequent slight decrease during days 11 and 12. Bound HMW fraction was positively correlated to irradiance, Peringia ulvae densities and temperature (Table 3).

Carbohydrate content from the LMW fractions showed a similar decreasing trend to the HMW colloidal and bound fractions between day 3 and day 5, and a subsequent increase until day 9 (maximum value of the survey) for the colloidal fraction before a new diminution. The signal of LMW carbohydrates of the 2 fractions resembled each other. Similarly to the HMW fraction, the signal for LMW of bound carbohydrates was less characterized by uncertainties than colloidal extracts and the maximum value was reached on day 10 (one day later than for colloidal carbohydrates).

Colloidal and bound LMW fractions were positively correlated to Peringia ulvae density (at the first rank among explanatory factors), but also, at the second rank, to bacterial abundance concerning the bound fraction and at the $4^{\text {th }}$ rank for colloidal EPS (Table 3). Bound 
LMW EPS were also positively correlated to pore water content and irradiance (Table 3), while colloidal LMW EPS were negatively correlated to temperature.

\section{Temporal patterns of carbohydrates in EPS: summer survey}

Among EPS, carbohydrate contents were all affected by spatial variations in summer (Table 2), however, when temporal effects were held constant, spatial effects were revealed for bound LMW and HMW fractions, but this was not the case for both colloidal fractions.

All HMW EPS fractions were affected by the day factor, even when hour effects were held constant (Table 1). Colloidal HMW carbohydrates were affected by hour effects during exposure periods, but not bound HMW carbohydrates (Table 1). The short-term temporal pattern of colloidal HMW carbohydrate was congruently similar to the one observed in winter, revealing the strong tidal effects. For colloidal carbohydrates, salinity takes the first place among explanatory factors (Table 3), with a positive influence. In addition, when normalized by $\operatorname{chl} a$, the positive relationship with salinity remains significant and the secretion of this EPS was considerably higher in summer $\left(0.979 \mu \mathrm{gEPS} . \mu \mathrm{g}\right.$ chl- $\left.a^{-1}\right)$ than in winter $(0.227 \mu \mathrm{gEPS} . \mu \mathrm{g}$

chl- $\left.a^{-1}\right)$. The relationships with both light and chl $a$ concentration in the $1^{\text {st }} \mathrm{cm}$ became negative during this period (Table 3). There was also a positive relationship with pore water content and a negative one with bacterial abundance.

Bound HMW carbohydrates increased during the first three days and then decreased progressively during the rest of the survey (Fig. 5C). Contrary to colloidal fraction, there was a strong negative effect of salinity on the amount of bound carbohydrate EPS (Table 3), and to a lesser extent, to pore water content (but only at the $5^{\text {th }}$ rank among explanatory factors). Other variables explaining the HMW bound EPS variation were chl $a$ concentration in the $1^{\text {st }} \mathrm{cm}$, light and chl $a$ concentration in the $1^{\text {st }} \mathrm{mm}$. The bound HMW temporal pattern was opposite to the one of colloidal carbohydrates, with a 3-day increase followed by a decrease between day 3 and 
5. The values varied less after with a small increase until day 7 and a weak diminution between day 7 and day 12. A new increase appeared on day 13 followed by a last decrease on the last day of the survey.

Colloidal LMW fraction was also affected by day as well as hour factors, but the bound LMW fraction was not affected by any temporal factor. The LMW carbohydrates were especially low in this season with weaker variations than in winter (between 1.01 and 20.8 $\mu \mathrm{g}_{\mathrm{EPS}} \mathrm{gDW} \mathrm{gW}^{-1}$ ). There was no significant variation for bound LMW carbohydrates and the variation of colloidal LMW carbohydrates remained very limited, except a small significant increase that was recorded on day 2. The colloidal LMW fraction showed a negative relationship with irradiance and Peringia ulvae density, and a positive one with pore water content (Table 3). The weak variations of bound LMW carbohydrates showed a positive relationship with pore water content and Peringia ulvae density, and to a lesser extent, by a negative one with temperature.

\section{Temporal pattern of proteins in EPS}

Proteins were absent in winter but present in summer. With values up to $4 \mu \mathrm{g} \cdot \mathrm{g}^{-1}$, they remained in small proportion compared to carbohydrate ( 10\%). Protein constituents showed an increasing pattern between subsequent days in summer (Fig. 6). Protein contents in EPS were affected by spatial effects as revealed by partial Mantel statistics (Table 1). Protein content temporal patterns were clearly distinguishable from those of carbohydrates. Contrary to carbohydrates, positive correlations were found between colloidal and bound proteins in summer $(\mathrm{R}=0.70, \mathrm{P}<0.0001)$. During the first two days of summer sampling, high protein contents in the two HMW fractions were followed by a decrease and a very gradual secretion, which accumulated at the surface of sediments day after day for 10 days around spring tides (Fig. 6A and 6B). Date effects were significant in summer for bound HMW fractions but they 
were not significant for colloidal HMW fraction, when temporal effects were held constant (Table 1). Differences between subsequent hours during exposure periods were not significant for proteins in EPS (Table 1). There was a strong negative relationship found between proteins of EPS and irradiance in summer for the 2 fractions (Table 3). This observation was the reverse of the one made for carbohydrates. For the 2 fractions, the other environmental factors contributing to the explanations of protein variations were salinity and pore water content with positive relationships (Table 3 ).

\section{DISCUSSION}

\section{Biofilm development}

Biofilms are often patchily distributed on the mudflat surface at a centimetric scale (Jesus et al., 2005; Paterson et al., 2000) and mostly self-organized (Weerman et al., 2010). The spatial distribution of chl $a$ concentration in the present study was in line with these findings during both summer and winter months. The spatial distribution of bacteria at the mudflat surface has been studied less frequently and was revealed as patchy as MPB for the 2 seasons (Table 2). Bacterial abundances were subject to high levels of temporal variability (between and within days). However, colloidal EPS contents did not display any patchiness in winter, while bound HMW and LMW fractions were affected by patchiness. The latter fractions correspond to the matrix surrounding benthic diatoms and this could explain the patchy distribution of these fractions in association to benthic diatoms. In summer, patchiness of carbohydrate EPS was also significant and, even though colloidal EPS could be subjected to dilution effects in the bulk sediment, their distribution seemed to be related to the patchy distribution of MPB, presumably because of the high production rate per cell in summer. Proteins were not detected in EPS during the winter survey, but there were affected by significant spatial variations in summer, even though they accounted for less than $10 \%$ of the 
total matrix (Table 2). In association to bound carbohydrates, they take part in the glycoprotein structures that are tightly associated to the cells of benthic diatoms (Flemming and Wingender, 2010).

The fluctuation of biomass of the uppermost $\mathrm{cm}$ of sediment peaked around the emersion period at noon. Similar to previous studies (Blanchard et al., 2001; Orvain et al., 2012), the tidal rhythm was observed to have an influence on the chl $a$ concentration, however, the effect was masked by other effects described in this study. The presence of the gastropod Peringia ulvae was a key parameter controlling the MPB biomass and the main differences observed between seasons were probably caused by grazing pressure. In summer, the density of the gastropod Peringia ulvae was 4-fold higher than that measured in winter. These snails are known to consume MPB populations (Haubois et al., 2005a), as confirmed by the negative correlation between $P$. ulvae and $1^{\text {st }} \mathrm{cm}$ chl $a$ concentration in summer and the strong negative relationship between $1^{\text {st }} \mathrm{mm}$ chl $a$ concentration and snail density in winter (Table 2). $P$. ulvae is also considered as both an herbivore and a bacterivor at relatively high ingestion rates (Pascal et al., 2008).There was a positive relationship between these two microorganism biomasses in summer, suggesting both bacteria and benthic diatoms are grazed intensely by the snails (Table 2). Indeed, the bacterial abundance also remained relatively stable during the two campaigns (ca $10^{8}$ cell per $\mathrm{m}^{2}$ ), and the lower values in summer were most likely caused by grazing by $P$. ulvae with a very dense snail population during this season compared to winter data. Bacterivory can explain the seasonal differences between standing stocks but this is not the main process controlling bacterial abundance during both surveys, since there was no negative correlation observed between snail density and bacterial abundance. Benthic bacteria can be considered as an alternative resource and the impact of top-down regulation was detected only in summer because of the general rarefaction of food items at this period (Pascal et al., 2008). The possible utilization of EPS as food source for macrofauna has already been mentioned in 
literature (Decho and Lopez, 1993). EPS can serve as alternative food items for snails in theory but, contrary to microorganisms, the EPS temporal patterns were not negatively impacted by snail presence (except for the colloidal LMW carbohydrates). In contrary they were positively related to snail density in winter.

For the 2 seasons, the chl $a$ concentration was higher than the minimum required for biofilm formation, ca. $25 \mathrm{mg} \mathrm{m}^{-2}$ (Guarini et al., 2000) and the chl $a$ concentration in the uppermost millimeter was in the same extent for the 2 seasons with high values between 15 and $35 \mathrm{mg}$ chl $a . \mathrm{m}^{-2}$. The biofilm was thus well constituted and active during the 2 surveys. The biofilm was better developed in summer as $31.2 \%$ of the Chl $a$ concentration from the $1^{\text {st }} \mathrm{cm}$ is accumulated in the $1^{\text {st }} \mathrm{mm}$, versus only $23.4 \%$ in winter. However, the winter temporal pattern revealed a rapid growth of the biofilm during 2 days (Fig. 2C). This chl $a$ concentration in the $1^{\text {st }} \mathrm{mm}$ was strongly impacted by presence of the snails in winter, as revealed by the negative relationship between them. In summer, the very high snail density seemed to prevent the biofilm from growing. There was also a strong negative relationship between $1^{\text {st }} \mathrm{mm} \operatorname{chl} a$ concentration with tidal amplitude along with light, temperature and salinity (Table 2). Apparently, the high level of irradiance and associated desiccation was not favorable for biofilm growth.

\section{LMW EPS: simply the result of hydrolysis?}

Carbohydrate contents from LMW fractions reached high values (Fig. 5B and 5D), whenever there was an increase in pore water content (Fig. 2D) and when salinity decreased, as happened during the winter survey (Fig. 2C). We obtained high correlation coefficients between carbohydrate content of LMW extracts and pore water content, at this season (Table 3). High LMW contents on day 7 (Fig. 5B and 5D) reinforced the idea that LMW compounds can be viewed as hydrolytic results of EPS breakdown since it was the single rainy day of the 
winter survey. On one hand, rainfall can wash away EPS from the surface of the sediment along with the occurrence of very abrupt hydrolysis, which could produce large amounts of small units of saccharides (Tolhurst et al., 2008). On the other hand, desiccation, revealed by extreme salinity and low moisture content at the end of emersion periods, also resulted in the total absence of LMW EPS during most of the summer survey and especially during the days with high irradiances.

The lack of LMW contents in summer sediments does not mean that they were not produced since their production can be balanced by a rapid utilization by heterotrophy or molecular breakdown via hydrolytic processes. It is difficult to establish if there is a direct production of LMW product by MPB. However, our summer results suggest that LMW EPS were not directly secreted by MPB but that only HMW compounds were secreted directly. LMW substances were produced afterwards only after EPS breakdown via hydrolysis or an enzymatic process linked to bacteria activity. As an alternative explanation, the clear relationship between pore water content and LMW contents may be also linked to the general positive relationship between pore water content and several parameters related to MPB, in relation to the hydrating properties of EPS (and maintaining porewater). Such a positive influence of EPS on pore water content, especially HMW colloidal EPS, has already been reported in past studies (Flemming and Wingender, 2010; Orvain et al., 2003). However, the positive relationship between HMW colloidal carbohydrates and porewater in summer illustrates the hydrating properties of these EPS, when the increase in salinity exerts a strong osmotic stress. In winter, the positive relationship between LMW EPS from the 2 fractions and porewater reflected a protecting role against salinity, thus reflect the positive role of rainfall on hydrolysis. Rainfall events clearly resulted in the direct massive accumulation of LMW compounds, and variations in pore water content appear to be an explanatory variable regulating the amount of LMW EPS in the bound as well as colloidal fractions. There were other causes 
of LMW accumulation, since the days 8 and 9 data in winter provide the maximal yield from this survey (Fig. 5B and 5D), and this cannot be explained by a rainfall event. These days were characterized by clear relative high bacterial abundances and also low irradiance and wind speed that could entail a low degree of evaporation/desiccation processes that could be favorable for hydrolysis.

A positive relationship between carbohydrate contents from LMW colloidal fraction and bacterial abundance was obtained in winter. Mc Kew et al. (2011) have demonstrated that enzymatic activities of bacteria decreased after sharp desiccation of sediment surface. Even though desiccation was not so pronounced in our field study, there could be an indirect effect of the decrease of pore water content on the bacterial development and activities that could amplify the accumulation of the LMW EPS after HMW EPS hydrolysis. The low abundance of bacteria found in summer could also contribute to the decrease in LMW compounds at sediment surfaces, since the liberation of LMW compounds by bacterial exoenzymes might be less active in interstitial pore water when the bacterial communities are less dense. It has already been demonstrated that bacteria can also degrade HMW components into LMW components through their exoenzyme activity (Haynes et al., 2007; Hofmann et al., 2009). This leads to an increase in LMW components, which can, in turn, be assimilated by prokaryotes. The bacterial cell wall acts as a sieve that can incorporate saccharides that are shorter than 500 - 600 Da (Nikaido, 2003). In surficial sediments, bacteria can develop on a substrate made up of nutrients, diatom EPS, and internal substances resulting from the decomposition of dead cells. The rapid transfer of carbon from carbohydrates in EPS is clearly established in the literature (Bellinger et al., 2009; Middelburg et al., 2000). The different bacterial groups do not adhere to the different EPS fractions to the same extent, so there is a wide range of heterotrophic bacteria that may be involved in the selective degradation and assimilation of EPS (Bellinger et al., 2009; Giroldo et al., 2003; Hofmann et al., 2009; Oakes et al., 2010). 


\section{The diversity of colloidal and bound EPS functions}

Since LMW compounds have been ascribed to hydrolysis and/or bacterial EPS breakdown, all further comments concern only HMW fractions that are designated EPS. The colloidal EPS temporal pattern were conspicuously similar at the two seasons. This reflected the very pronounced effect of the tidal amplitude along with exposure to light on EPS secretion (Fig. 2B), since the day-after-day tidal delay clearly determines the degree of light received by the biofilm during exposure periods. A positive relationship between carbohydrate content from colloidal HMW EPS and irradiance was obtained in winter. This confirmed the fact that their production is tightly linked to photosynthesis activities, as already reported in the literature (Smith and Underwood, 1998; Underwood et al., 2004). In turn, this was confirmed by the significant positive correlation between colloidal EPS/chl $a$ ratios and temperature. In summer, there was a negative correlation found between colloidal EPS and irradiance. This can be explained by a delay lasting several days between primary production and carbon reallocation from internal glucans for EPS secretion (Smith and Underwood, 1998). Moreover, the secretion pathway of colloidal EPS was clearly stimulated in summer especially when salinity stress increased either because colloidal EPS were involved in protecting the biofilm against desiccation or because they are involved in vertical migration involving the production of colloidal EPS in the microenvironment of benthic diatoms, which could be enhanced in the case of high salinities. The latter hypothesis about a stimulation of migration involving EPS because of a salinity stress has never been formulated until now, and must be explored in further studies. In summer, a significant correlation was observed between salinity and colloidal EPS (and also when the data were standardized by chl $a$ unit). This salinity effect could also mask the relationship between EPS production and light absorption in summer. A simple effect of high salinity on the lack of hydrolysis of HMW compounds cannot explain the whole set of correlations. High salinity in superficial sediments during the summer survey may also have 
caused saline stress leading to the high HMW colloidal EPS contents that were found (and presumably secretion metabolism).

The colloidal fraction is especially rich in glucose (Bellinger et al., 2009; Hanlon et al., 2006; Pierre et al., 2012) and in uronic acids (Pierre et al., 2012). This sugar composition must be very hydrophilic and very efficient to retain interstitial pore water and protect cells against desiccation. Some diatoms excrete EPS that form the viscous mucilage that surrounds cells (Underwood and Paterson, 2003) and probably play an important role in cell protection when conditions at the mud surface become unfavorable. This biofilm context should also be related to the weak chl $a$ concentration in the $1^{\text {st }} \mathrm{mm}$ and the negative effect of light. The cell protection of benthic diatoms to extreme salinity has been reported for sea ice, where microalgae excreted EPS to buffer and cryoprotect themselves from potential ice-crystals and impairments caused by high salinity (Krembs et al., 2002). During the summer survey, salinity increased during each emersion period with rapid salinity peaks during spring tides, when the quantity of light received by the sediment surface was maximal (Fig. 2B and 2C). Diatoms may have responded by secreting very large quantities of colloidal carbohydrates during the two first hours of days 8-12, when salinity reached its highest values of the 14-day kinetics, to ensure protection of their cells against osmotic stress and to maintain porewater at the sediment surface despite rapid desiccation (Fig. 5A). This could explain the paradox of the positive relationship found between colloidal carbohydrates with 2 opposite factors: the salinity and the sediment porewater content (Table 3). The pool of carbohydrate in the colloidal HMW fraction increased rapidly between the 2 first hours and stopped increasing or decreased during the subsequent hours during this episode with high salinity (summer, day 8-12, Fig. 5A). Protecting themselves from desiccation and extreme salinity, diatom likely secreted large quantities of colloidal EPS when salinity increased drastically. Apparently, this was especially the case during the early stage of the air exposure periods (de Brouwer and Stal, 2001, Hanlon et al., 2006; Perkins et al., 2001; Staats 
et al., 2000b). The colloidal carbohydrate could be implied in the formation of a protective wall, supplying hydrophilic and stabilizing properties that could convey important functions to the biofilm matrix in terms of resistance to environmental stress.

Proteins in EPS were absent in winter and represented a very small proportion of EPS in summer ( $7 \%$ of total EPS and $10 \%$ when regarding only HMW fractions). The protein fraction of colloidal and bound EPS could also contribute to the protective properties of this fraction in summer, since they were related to variables that could reflect an environmental stress (excess in salinity, high light regime). Positive correlation between protein contents from colloidal and bound fractions were obtained in summer, contrary to what was observed concerning carbohydrates. In winter, which could be a period without strong environmental stress for the biofilm, there was a lack of proteins in HMW EPS. In fact, protein contents of bound EPS in summer were better explained by ecological factors modifying surface properties of sediment instead of microorganisms. For instance, there was a negative relationship with irradiance and a positive relationship with salinity in summer (Table 3). This result suggests that proteins from EPS secretion was stimulated when the biofilm was constrained to resist to environmental stresses. Protein contents from EPS in summer were also implied in the paradoxical result concerning the positive relationships with salinity and pore water content at the same time. This could reflect the stimulation of this protective substance by extreme salinity, then rehydrating sediments.

Despite their low proportion in EPS, proteins appeared to be a good indicator of the maintenance of biofilm and, in summer, they were produced some days before significant increases of the standing stock of chl- $a$ concentration in the $1^{\text {st }} \mathrm{cm}$ (and the $1^{\text {st }} \mathrm{mm}$ chl $a$ concentration remained relatively stable all along the survey). In summer, protein content of bound and colloidal fractions slowly increased for 10 days until the end of the survey, after two days without proteins at the beginning of the survey (days 3 and 4 - Fig. 6). This increase may 
be linked to the resistance of the biofilm structure to strong irradiance and salinities, since the production of proteins in EPS is incessant with the initiation of the pattern preceding a small net increase in MPB biomass. Protein temporal pattern likely indicated the role of EPS in biofilm construction. Indeed, the summer temporal pattern of protein contents from both colloidal and bound fractions displayed a remarkably progression. Moreover, there was a negative correlation between protein content of these EPS and light, contrary to carbohydrate components, the latter being clearly attributable to a secretion pathway connected to photosynthesis. Some authors already demonstrated that the coverage of a substrate by the EPS matrix occurred before the production of $\operatorname{chl} a$, with a small amount of EPS produced by diatoms during their locomotion during the biofilm construction (Gerbersdorf et al., 2009; Lubarsky et al., 2010; Orvain et al., 2003; Rincé et al., 1999). Lab studies (Gerbersdorf et al., 2009 ; Lubarsky et al., 2010) have clearly shown that the protein content of bound EPS fraction plays a role in pioneering stages as biofilm bricks, probably by facilitating attachment of the cell to a surface and also cell-cell interaction, which could be important in the first stages of the development of the biofilm matrix. The protein part of the EPS should constitute a matrix that is very persistent, since values did not decrease from one day to the next during the 10-day increase in summer and this could be related to the resistance of proteins (or the protein parts of proteoglycans and/or glycoproteins) to the uprising seawater during the flood return. The continuous accumulation of protein contents at the surface of sediments with time has already been reported in the literature (Gerbersdorf et al., 2009; Lubarsky et al., 2010), while carbohydrates are more subject to hydrolysis and exportation in the water column (Hanlon et al., 2006; Orvain et al., 2003).

Whatever was the source of proteins in EPS (bacteria or MPB), the positive correlations between bacteria and MPB in summer as well as positive correlations between protein contents from colloidal and bound extracts, suggest the existence of mutual advantage between bacteria 
and MPB during biofilm development and that positive interaction may occur when both communities are relatively sparse. Synergistic effects between autotrophic and heterotrophic microorganisms have already been demonstrated in terms of EPS secretion and especially the contribution of proteins (Gerbersdorf et al., 2009; Lubarsky et al., 2010). Our summer results suggest such synergistic effects between bacteria, microalgae and EPS (van Duyl et al., 2000; Gerbersdorf et al. 2009, Lubarsky et al., 2010; Lundkvist et al., 2007), since bacteria and diatoms were positively correlated in summer. Such positive association between MPB and bacteria was not detected in winter, along with the absence of proteins in EPS. This could simply be due to a direct trophic linkage since protease activity can be much higher than that of glucosidase (Smith et al., 1992). Protein could be more efficiently solubilized than polysaccharide and hence more available as a substrate for bacteria in summer.

In summer, the carbohydrate contents from the bound and colloidal fractions were negatively correlated and they clearly resulted from different metabolic pathways (Fig. 5A and 5C). They could have different functions for benthic diatoms, when environmental factors are more constraining (Orvain et al. 2003). The carbohydrate content from bound EPS also appears to be associated with the structural development of the biofilm and to play a role in the biofilm matrix with protein components when the MPB communities are the most subject to unfavorable conditions and require resistance of the biofilm at the sediment surface. The carbohydrate content of the bound EPS seems to be related to MPB biomass rather than bacteria (especially in summer) and this EPS variable was also well explained by irradiance in the multiple regression model during the 2 seasons.

Bacterial abundances were correlated to none of the environmental parameters in winter. However, when including EPS fractions in the set of correlation, there was a negative correlation between bacterial abundance and bound EPS that appeared in winter. This was the single significant correlation with bacterial abundance. This observation raises a specific 
question about a potential negative influence of bound EPS on bacteria development. The bacterial abundance increase when bound EPS carbohydrates were absent at the beginning of the survey and the negative correlation suggests a negative influence of EPS components on bacterial development in winter. Bound EPS secreted by benthic diatoms could be involved in such phenomena, especially the carbohydrate content, which reached high values as the bacteria cell numbers decrease from days 5 to day 9 (Figs. 3B and 5C). Inhibitory effects of bound EPS on bacteria development were evidenced in winter, when chl $a$ concentration and EPS secretion were higher, whereas top-down regulation by Peringia ulvae in summer appears to limit such effects. In winter, there was also an absence of proteins in EPS and the protein enrichment from EPS could play a role in synergetic effects between the two communities of microorganisms (as observed in summer). In winter, the monomeric composition of bound EPS is especially enriched in deoxy sugars (Pierre et al., 2014). This specific richness in deoxy sugar of bound EPS carbohydrates was previously observed in literature (Giroldo et al., 2003; Takahashi et al., 2009) and this specific composition could be implied in a negative interaction between both microorganisms as it has been put in evidence in a mesocosm study (Agogué et al., 2014). EPS have already been described as a bacterial development regulator (Lubarsky et al., 2010; Smith et al., 1995) or more precisely as an inhibitor of bacterial development (Smith et al., 1995). For instance, Smith et al. (1995) found that the marine diatom Phaeodactylum tricornutum has an antibacterial effect on Gram-negative and gram-positive bacteria by means of a fatty acid that has several antibacterial components (Desbois et al., 2008). A study conducted on other diatom species showed that some have an antibacterial effect (Walksman and Butler, 1937). This was the case of the Nitzschia genus and numerous species of this genus belong to the community observed in MOB intertidal flats (Haubois et al., 2005b).

\section{CONCLUSION}


The present field study confirmed that the amount of colloidal EPS carbohydrates in sediments was positively related to MPB activity and to a direct effect of sunlight on biofilm photobiology that conduced to remarkable similarities in the 14-day temporal pattern. Even if there were high production rates of HMW-EPS in summer, the seasonal tendencies revealed a strong grazing pressure of Peringia ulvae on biofilm development in summer and this biofilm consumption must explain why the standing stocks of MPB and bacteria became very low. This observation suggests a direct metabolic pathway between colloidal EPS and photosynthesis. LMW EPS temporal pattern were not directly related to MPB concentrations or light, but they rather reflect the intensity of hydrolysis processes regulated by pore water temporal pattern, rainfall and bacterial abundances. Colloidal EPS also appear to be involved in the protection of diatom cells against the extreme salinity recorded during the summer survey, since colloidal EPS contents were much pronounced, when salinity transcended the critical threshold of $45 \%$ (observed on day 8). The carbohydrate bound EPS, which were as abundant as colloidal EPS, may be involved in the cell-cell communication of the bacteria-diatom consortium along with adhering properties, both processes that are expected to contribute to the development of biofilm as well as to surface colonization. The pioneering stages of biofilm development seemed to be characterized by the secretion of protein-rich mucilage, which can be secreted by diatoms as well as by bacteria, and may help both microorganisms to structure the developing biofilm in summer, by inferring resistance to strong light and salinities. Proteins were absent from EPS in winter and this could induce an absence of synergistic relationships at this period, since the positive relationship between them in summer disappeared at this period, while bacterial abundance was negatively correlated to bound EPS carbohydrates. There is a need for new studies on interactions with microphytobenthic biofilms in controlled laboratory conditions to test hypotheses concerning the secretion of protein-rich EPS during the pioneering stages of biofilm development, the synergy between MPB and bacteria during biofilm development when 
bound EPS have high protein contents, and the potential antibacterial effects of compounds related to EPS, when proteins are absent from bound EPS.

\section{ACKOWLEDGEMENTS}

This work was supported by the French ANR (National Research Agency) through the VASIREMI Project "Trophic significance of microbial biofilms in tidal flats" (Contract ANR06-BLAN-0393-01). The authors are grateful to the scientific community of VASIREMI with special thanks to Caroline Nérot, Pascale Moulin, Martine Bréret, Françoise Mornet, Pierre Richard for their support during this study. We also sincerely thank the 2 students who participated to EPS analyses: Georges Semedo Cabral Georges and Apolline Clet. We are grateful to Dany Prevostat (Aeroglisseurs Services) for technical support during the field survey. Finally, we are very grateful to 3 anonymous referees for their very useful comments to improve the quality of the manuscript.

\section{REFERENCES}

Abdullahi AS, Underwood, G.J.C., Gretz, M.R., 2006. Extracellular matrix assembly in diatoms (Bacillariophyteae). V. Environmental effects on polysaccharide synthesis in the model diatom Phaedactylum tricornutum. Journal of Phycology 378, 363-378.

Admiraal, W., Peletier, H., Brouwer, T., 1984. The seasonal succession patterns of diatom species on an intertidal mudflat - an experimental analysis. Oikos 42, 30-40.

Agogué, H., Mallet, C., Orvain, F., De Crignis, M., Mornet, F., Dupuy, C., 2014. Bacterial dynamics in a microphytobenthic biofilm: a tidal mesocosm approach. Journal of Sea Research, this issue.

Amon, R., Benner, R., 1996. Bacterial utilization of different size classes of dissolved organic matter. Limnology and Oceanography 41, 41-51.

Bellinger, B., Underwood, G., Ziegler, S., Gretz, M., 2009. Significance of diatom-derived polymers in carbon flow dynamics within estuarine biofilms determined through isotopic enrichment. Aquatic Microbial Ecology 55, 169-187. 
Blanchard, G.F., Guarini, J.-M., Orvain, F., Sauriau, P.-G., 2001. Dynamic behaviour of benthic microalgal biomass in intertidal mudflats. Journal of Experimental Marine Biology and Ecology 264, 85-100.

Bradford, M., 1976. A Rapid and Sensitive Method for the Quantitation of Microgram Quantities of Protein Utilizing the Principle of Protein-Dye Binding. Analytical biochemistry $72,248-254$.

de Brouwer, J.F.C., Stal, L., 2001. Short-term dynamics in microphytobenthos distribution and associated extracellular carbohydrates in surface sediments of an intertidal mudflat. Marine Ecology Progress Series 218, 33-44.

de Brouwer, J.F.C., Wolfstein, K., Ruddy, G.K., Jones, T.E.R., Stal, L.J., 2005. Biogenic stabilization of intertidal sediments: the importance of extracellular polymeric substances produced by benthic diatoms. Microbial ecology 49, 501-12.

Cammen, L., 1991. Annual bacterial production in relation to benthic microalgal production and sediment oxygen uptake in an intertidal sandflat and an intertidal mudflat. Marine Ecology Progress Series 71, 13-25.

Chiovitti, A.H., Molino, P., Crawford, S., Teng, R., Spurck, T., Wetherbee, R., 2004. The glucans extracted with warm water from diatoms are mainly derived from intracellular chrysolaminaran and not extracellular polysaccharides. European Journal of Phycology 39, 117-128.

Chiovitti, A. H., Michael, J., Harper, R.E., Wetherbee, R., Bacic, A., 2003. The complex polysaccharides of the diatom Pinnularia viridis (Bacillariophyceae). Journal of Phycology 554, 543-554.

Decho, A.W., 1990. Microbial exopolymer secretions in ocean environments: their role(s) in food webs and marine processes. Oceanographic marine biology annual Review 28, 73 153.

Decho, A.W., 2000. Microbial biofilms in intertidal systems : an overview. Continental Shelf Research 20, 1257-1273.

Decho, A.W., Lopez, G.R., 1993. Exopolymer microenvironments of microbial flora : Multiple and interactive effects on trophic relationships. Limnologica - Ecology and Management of Inland Waters 38, 1633-1645.

Desbois, A.P., Lebl, T., Yan, L., Smith, V.J., 2008. Isolation and structural characterisation of two antibacterial free fatty acids from the marine diatom, Phaeodactylum tricornutum. Applied microbiology and biotechnology 81, 755-64.

Dubois, M, Gilles, KA, Hamilton, JK, Rebers, PA, Smith, F., 1956. Colorimetric method for determination of sugars and related substances. Analytical Chemistry 28, 350-356.

van Duyl, F.C., Winder, B.D., Kop, A.J., Wollenzien, U., 2000. Consequences of diatom mat erosion for carbohydrate concentrations and heterotrophic bacterial activities in intertidal sediments of the Ems-Dollard estuary. Continental Shelf Research 20, 1335-1349. 
Flemming, H.-C., Wingender, J., 2002. What biofilms contain - polysaccharides, proteins...etc. Chemie in unserer zeit 36, 30-42.

Flemming, H.-C., Wingender, J., 2010. The biofilm matrix. Nature reviews. Microbiology 8, 623-633.

Fortin, M., Gurevitch, J., 2001. Mantel tests: spatial structure in field experiments. In: Scheiner, SM, Gurevitch, J. (Ed.), Design and Analysis of Ecological Experiments. Oxford University Press, New York, pp. 308-326.

Gerbersdorf, S.U., Manz, W., Paterson, D.M., 2008. The engineering potential of natural benthic bacterial assemblages in terms of the erosion resistance of sediments. FEMS microbiology ecology 66, 282-94.

Gerbersdorf, S.U., Westrich, B., Paterson, D.M., 2009. Microbial extracellular polymeric substances (EPS) in fresh water sediments. Microbial ecology 58, 334-49.

Giroldo, D., Vieira, A., Paulsen, B., 2003. Relative increase of deoxy sugars during microbial degradation of an extracellular polysaccharide released by a tropical freshwater Thalassiosira sp (Bacillariophyceae). Journal of Phycology 39, 1109-1115.

Giroldo, D., Vieira, A., Paulsen, B., 2005. Extracellular polysaccharides produced by a tropical cryptophyte as a carbon source for natural bacterial populations. European Journal of Phycology 40, 241-249.

Guarini, J.-M., Blanchard, G.H.F., Gros, P., 2000. Quantification of the microphytobenthic primary production in European intertidal mudflats: a modelling approach. Continental Shelf Research 20, 1771-1788.

Hamels, I., Muylaert, K., Casteleyn, G., Vyverman, W., 2001. Uncoupling of bacterial production and flagellate grazing in aquatic sediments: a case study from an intertidal flat. Aquatic Microbial Ecology 25, 31-42.

Hanlon, A.R.M., Bellinger, B., Haynes, K., Xiao, G., Hofmann, T. A., Gretz, M.R., Ball, A. S., Osborn, A. M., Underwood, G.J.C., 2006. Dynamics of extracellular polymeric substance (EPS) production and loss in an estuarine, diatom-dominated, microalgal biofilm over a tidal emersion-immersion period. Limnology and Oceanography 51, 79-93.

Haubois, A.-G., Guarini, J.-M., Richard, P., Fichet, D., Radenac, G., Blanchard, G.F., 2005a. Ingestion rate of the deposit-feeder Hydrobia ulvae (Gastropoda) on epipelic diatoms: effect of cell size and algal biomass. Journal of Experimental Marine Biology and Ecology 317, 1-12.

Haubois, A.-G., Sylvestre, F., Guarini, J.-M., Richard, P., Blanchard, G.F., 2005b. Spatiotemporal structure of the epipelic diatom assemblage from an intertidal mudflat in Marennes-Oléron Bay, France. Estuarine, Coastal and Shelf Science 64, 385-394.

Haynes, K., Hofmann, T. a, Smith, C.J., Ball, A.S., Underwood, G.J.C., Osborn, A.M., 2007. Diatom-derived carbohydrates as factors affecting bacterial community composition in estuarine sediments. Applied and environmental microbiology 73, 6112-6124. 
Hoagland, K., Rosowski, J., Gretz, M., Roemer, S., 1993. Diatom extracellular polymeric substances - function, fine-structure, chemistry, and physiology. Journal of Phycology 29, 537-566.

Hofmann, T., Hanlon, A., Taylor, J., Ball, A., Osborn, A., Underwood, G., 2009. Dynamics and compositional changes in extracellular carbohydrates in estuarine sediments during degradation. Marine Ecology Progress Series 379, 45-58.

Jesus, B., Brotas, V., Marani, M., Paterson, D.M., 2005. Spatial dynamics of microphytobenthos determined by PAM fluorescence. Estuarine, Coastal and Shelf Science 65, 30-42.

Krembs, C., Eicken, H., Junge, K., Deming, J., 2002. High concentrations of exopolymeric substances in Arctic winter sea ice: implications for the polar ocean carbon cycle and cryoprotection of diatoms. Deep Sea Research Part I: Oceanographic Research Papers 49, 2163-2181.

Legendre, P., Legendre, L., 1998. Numerical Ecology, Developments in Environmental Modelling 20. Elsevier Sciences, Amsterdam. 843 pp.

Lorenzen, S., 1966. A method for the continuous measurement of in vivo chlorophyll concentration. Deep-sea research 13, 265-275.

Lubarsky, H.V., Hubas, C., Chocholek, M., Larson, F., Manz, W., Paterson, D.M., Gerbersdorf, S.U., 2010. The stabilisation potential of individual and mixed assemblages of natural bacteria and microalgae. PloS one 5, e13794.

Lundkvist, M., Gangelhof, U., Lunding, J., Flindt, M.R., 2007. Production and fate of extracellular polymeric substances produced by benthic diatoms and bacteria: A laboratory study. Estuarine, Coastal and Shelf Science 75, 337-346.

MacIntyre, H., Cullen, J., 1996. Primary production by suspended and benthic microalgae in a turbid estuary: time-scales of variability in San Antonio Bay, Texas. Marine Ecology Progress Series 145, 245-268.

Mann KH, 1982. The Ecology of Coastal Waters: A Systems Approach. Blackwell, Oxford.

McKew, B.A., Taylor, J.D., McGenity, T.J., Underwood, G.J.C., 2011. Resistance and resilience of benthic biofilm communities from a temperate saltmarsh to desiccation and rewetting. The International Society for Microbial Ecology journal 5, 30-41.

Middelburg, J.J., Barranguet, C., Boschker, H.T.S., Herman, P.M.J., Moens, T., Heip, C.H.R., 2000. The fate of intertidal microphytobenthos carbon: an in situ ${ }^{13} \mathrm{C}$-labeling study. Limnology and oceanography 45, 1224-1234.

Nikaido, H., 2003. Molecular basis of bacterial outer membrane permeability revisited. Microbiology and molecular biology reviews 67, 593-656.

Oakes, J.M., Eyre, B.D., Middelburg, J.J., Boschker, H.T.S., 2010. Composition, production, and loss of carbohydrates in subtropical shallow subtidal sandy sediments: Rapid 
processing and long-term retention revealed by ${ }^{13} \mathrm{C}$-labeling. Limnology and Oceanography 55, 2126-2138.

Orvain, F., Galois, R., Barnard, C., Sylvestre, A., Blanchard, G., Sauriau, P.-G., 2003. Carbohydrate production in relation to microphytobenthic biofilm development: an integrated approach in a tidal mesocosm. Microbial ecology 45, 237-251.

Orvain, F., Lefebvre, S., Montepini, J., Sébire, M., Gangnery, A., Sylvand, B., 2012. Spatial and temporal interaction between sediment and microphytobenthos in a temperate estuarine macro-intertidal bay. Marine Ecology Progress Series 458, 53-68.

Pascal, P.-Y., Dupuy, C., Richard, P., Haubois, A.-G., Niquil, N., 2008. Influence of environment factors on bacterial ingestion rate of the deposit-feeder Hydrobia ulvae and comparison with meiofauna. Journal of Sea Research 60, 151-156.

Paterson, D.M., Tolhurst, T.J., Kelly, J.A., Honeywill, C., de Deckere, E.M.G.., Huet, V., Shayler, S.A., Black, K.S., Brouwer, J.D., Davidson, I., 2000. Variations in sediment properties, Skeffling mudflat, Humber Estuary, UK. Continental Shelf Research 20, 1373 1396.

Perkins, R., Underwood, G., Brota, V., Snow, G., Jesus, B., L, R., 2001. Responses of microphytobenthos to light: primary production and carbohydrate allocation over an emersion period. Marine Ecology Progress Series 223, 101-112.

Perkins, R.G., Honeywill, C., Consalvey, M., Austin, H.A., Tolhurst, T.J., Paterson, D.M., 2003. Changes in microphytobenthic chlorophyll $a$ and EPS resulting from sediment compaction due to de-watering: opposing patterns in concentration and content. Continental Shelf Research 23, 575-586.

Perkins, R.G., Paterson, D.M., Sun, H., Watson, J, Player, M.A., 2004. Extracellular polymeric substances: quantification and use in erosion experiments. Continental Shelf Research 24, 1623-1635.

Pierre, G., Graber, M., Rafiliposon, B.A., Dupuy, C., Orvain, F., De Crignis, M., Maugard, T., 2012. Biochemical composition and changes of extracellular polysaccharides (ECPS) produced during microphytobenthic biofilm development (Marennes-Oléron, France). Microbial ecology 63, 157-169.

Pierre, G., Zhao, J.M., Orvain, F., Dupuy, C., Graber, M., Maugard, T. 2014. Seasonal dynamics of extracellular polymeric substances (EPS) in surface sediments of a diatomdominated intertidal mudflat (Marennes-Oléron, France). Journal of Sea Research, this issue.

Porter, K., Feig, Y., 1980. The use of DAPI for identifying and counting aquatic microflora. Limnology and oceanography 25, 1943-1948.

Rincé, A., Lebeau, T., Robert, J.M., 1999. Artificial cell-immobilization: a model simulating immobilization in natural environments? Journal of applied phycology 11, 263-272. 
Schmidt, J., Deming, J., Jumars, P., Keil, R., 1998. Constancy of bacterial abundance in surficial marine sediments. Limnology and oceanography 43, 976-982.

Smith, D., Simon, M., Alldredge, A., Azam, F., 1992. Intense hydrolytic enzyme activity on marine aggregates and implications for rapid particle dissolution. Nature 359, 139-142.

Smith, D.C., Steward, G.F., Long, R.A., Azam, F., 1995. Bacterial mediation of carbon fluxes during a diatom bloom in a mesocosm. Deep Sea Research Part II: Topical Studies in Oceanography 42, 75-97.

Smith, D.J., Underwood, G.J.C., 1998. Exopolymer production by intertidal epipelic diatoms. Limnology and Oceanography 43, 1578-1591.

Staats, N., Stal, L., Mur, L., 2000. Exopolysaccharide production by the epipelic diatom Cylindrotheca closterium: effects of nutrient conditions. Journal of experimental marine biology and ecology 249, 13-27.

Staats, N., Stal, L.J., Winder, B.D., Mur, L., 2000. Oxygenic photosynthesis as driving process in exopolysaccharide production of benthic diatoms. Marine Ecology Progress Series 193, 261-269.

Takahashi, E., Ledauphin, J., Goux, D., Orvain, F., 2009. Optimising extraction of extracellular polymeric substances (EPS) from benthic diatoms: comparison of the efficiency of six EPS extraction methods. Marine and Freshwater Research 60, 1-10.

Tolhurst, T.J., Watts, C.W., Vardy, S., Saunders, J.E., Consalvey, M.C., Paterson, D.M., 2008. The effects of simulated rain on the erosion threshold and biogeochemical properties of intertidal sediments. Continental Shelf Research 28, 1217-1230.

Underwood, G., Kronkamp, R., 1999. Primary production by phytoplankton and microphytobenthos in estuaries. Advances in ecological research 29, 93-153.

Underwood, G., Paterson, D., 2003. The importance of extracellular carbohydrate production by marine epipelic diatoms. Advances in botany research 40, 183-240.

Underwood, G.J.C., Boulcott, M., Raines, C.A., Waldron, K., 2004. Environmental effects on exopolymer production By Marine benthic Diatoms: dynamics, changes in composition, and pathways of production. Journal of Phycology 40, 293-304.

Walksman, S.A., Stokes, J.L., Butler, M.R., 1937. Relation of bacteria to diatom in sea water. Journal of Marine Biological Association U.K. 22, 359-373.

Weerman, E.J., Koppel, J.V.D., Eppinga, M.B., Liu, Q.-X., Herman, P.M.J., 2010. Spatial SelfOrganization on Intertidal Mudflats through Biophysical Stress Divergence. The American Naturalist 176.

Yallop, M., Paterson, D., Wellsbury, P., 2000. Interrelationships between rates of microbial production, exopolymer production, microbial biomass, and sediment stability in biofilms of intertidal sediments. Microbial ecology 39, 116-127. 


\section{LIST OF FIGURES}

Fig. 1: Field sampling. A: location of the study area; B: surface area sampled and sampling design.
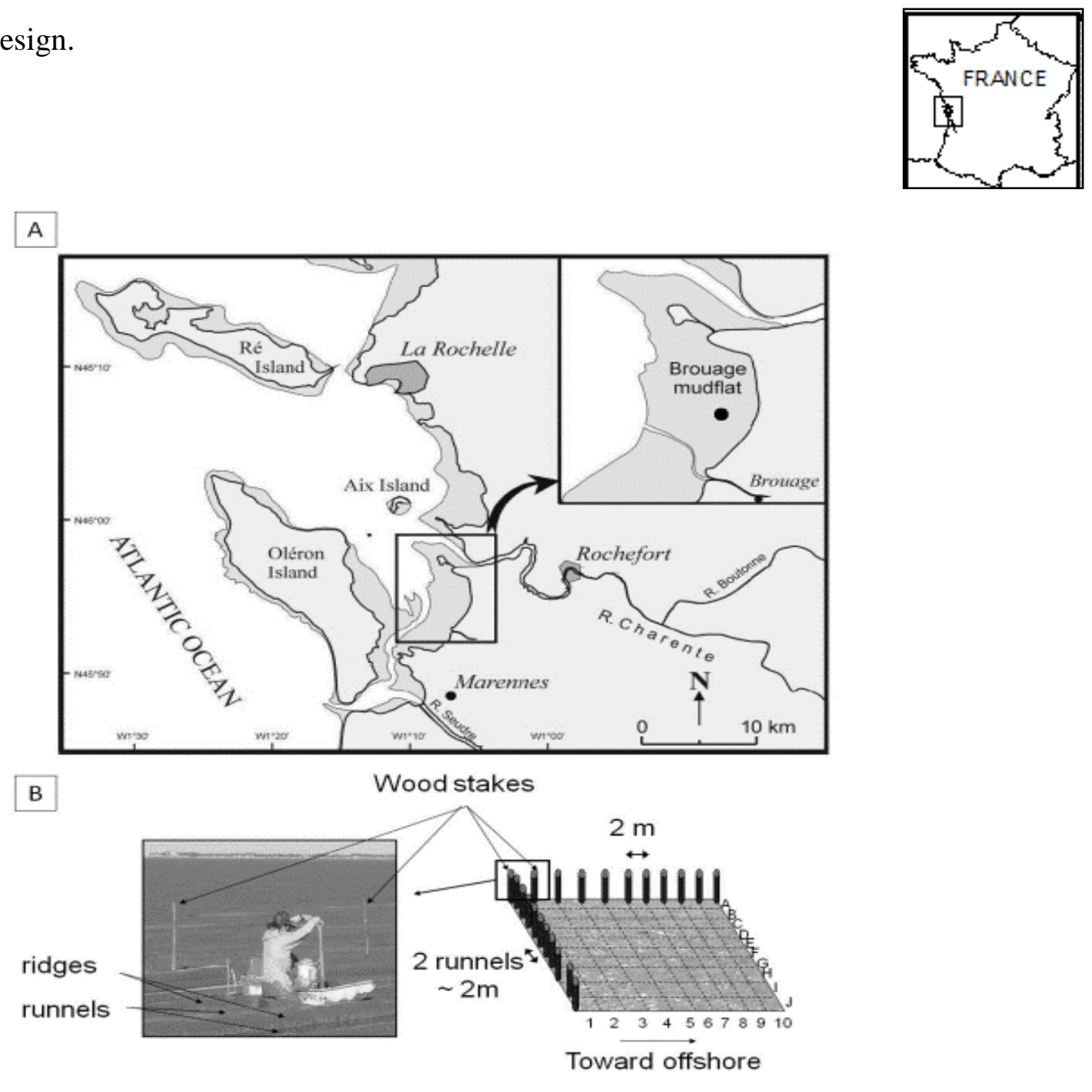

Fig. 2: Ecological factors on the mudflat during the winter sampling period (gray squares) and summer (black circles) at each sampling. A: tidal amplitude (to make apposite comparisons between the seasons, maximum values were superimposed); B: irradiance measured at the surface of the mudflat ( $\mu$ mol photons $\mathrm{m}^{-2} \mathrm{~s}^{-1}$ ) at each sampling (presented chronologically during low tide); C: pore water salinity (PSU) at each sampling, each day (presented chronologically during low tide); D: Pore water content $(\%)$; E: Mean temperature $\left({ }^{\circ} \mathrm{C}\right)$ at each 
sampling; F: Rainfall (mm, black and grey bars) and wind speed ( $\mathrm{m} \mathrm{s}^{-1}$, grey squares and black circles); G : Density of the gastropod Peringia ulvae (in $10^{3}$ ind. $\mathrm{m}^{-2}$ ).
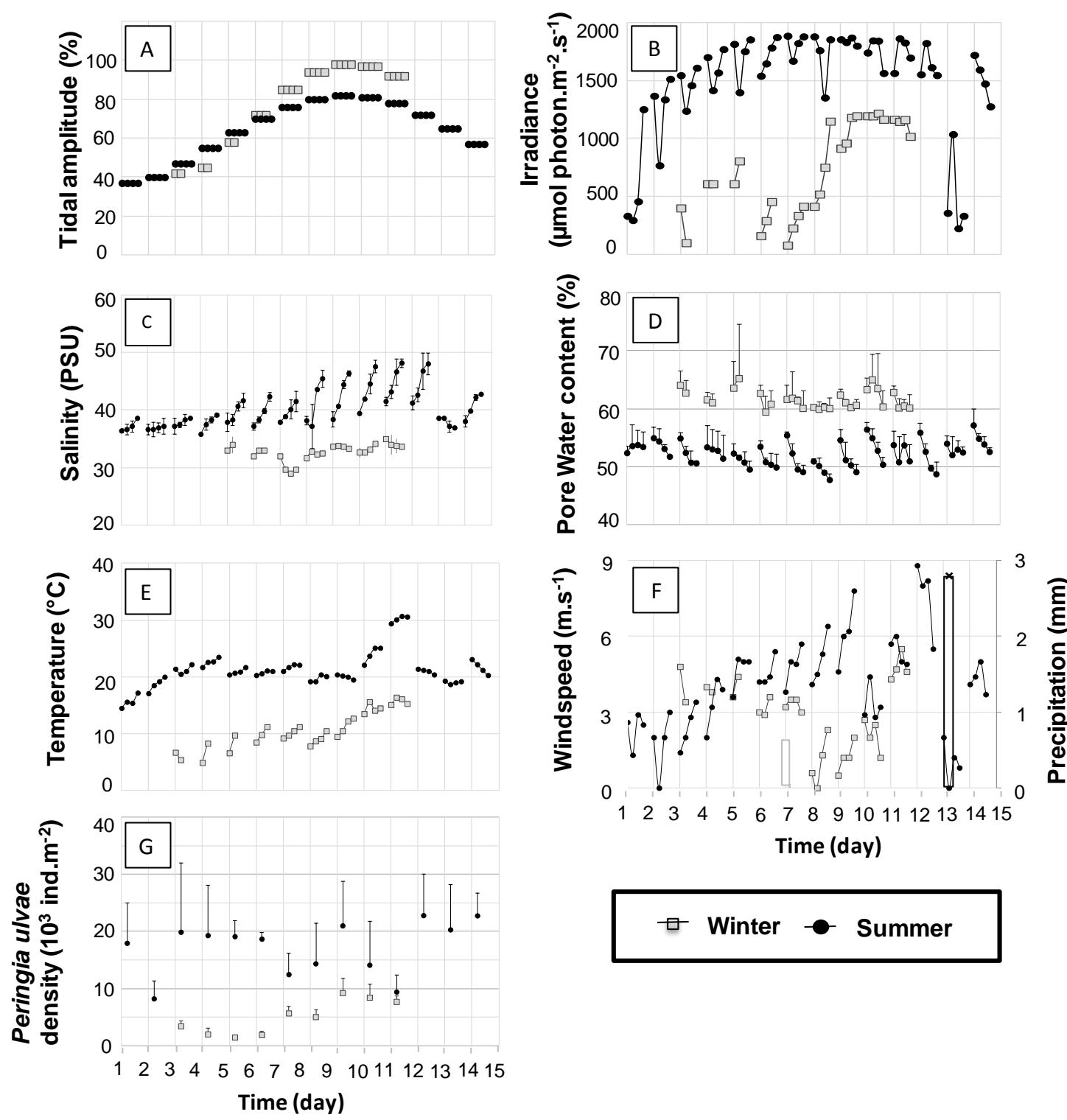
Fig. 3: Temporal dynamics of: A) $1^{\text {st }} \mathrm{cm}$ chl $a$ concentration $\left(\mathrm{mg} \cdot \mathrm{m}^{-2}\right)$ in the uppermost $\left.\mathrm{cm}, \mathrm{B}\right)$ $1^{\text {st }} \mathrm{cm}$ bacterial abundance (cell $\mathrm{m}^{-2}$ ) and C) $1^{\text {st }} \mathrm{mm}$ chl $a$ concentration ( $\mathrm{mg} \cdot \mathrm{m}^{-2}$ estimated from PAM fluorescence) measured during low tide in winter (gray squares) and summer (black circles). Error bars: standard deviations measured in the three replicates (only the positive standard deviation is shown).
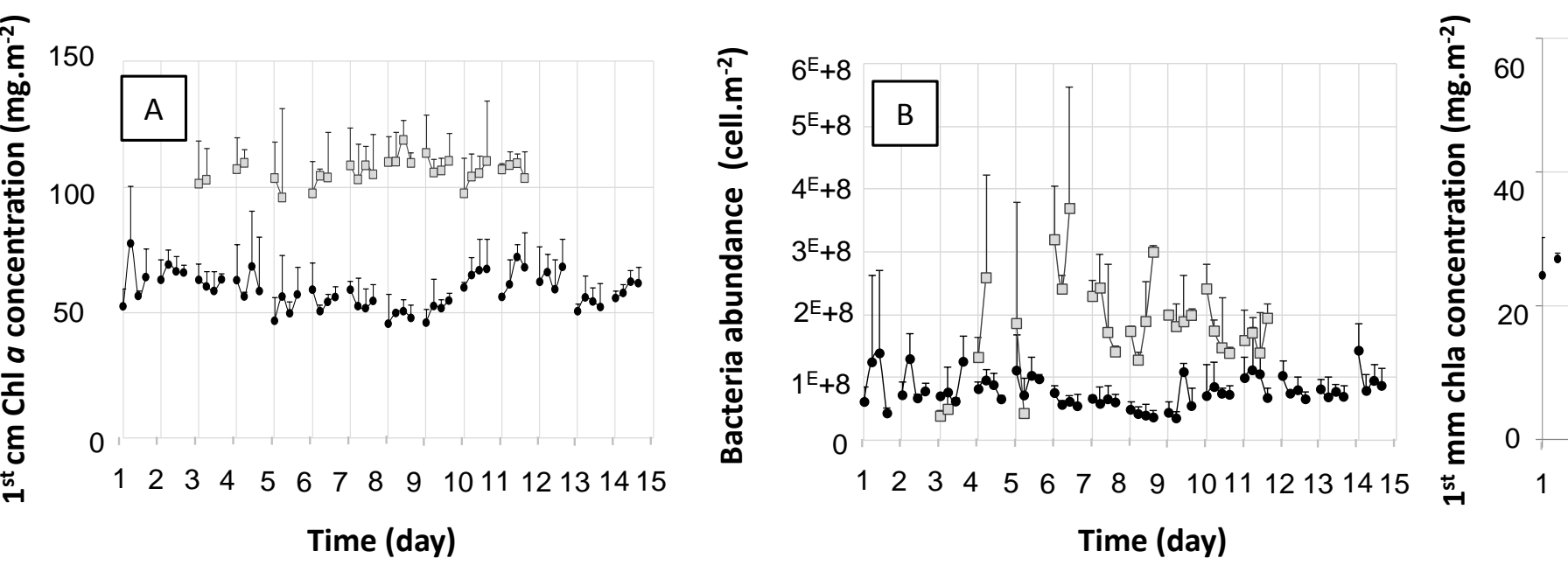
Fig. 4: Distribution from Colloidal (C) and bound (B) EPS with carbohydrates (C) and proteins (P) separated between LMW (L) and HMW (H) fractions in summer (left) and in winter (right). For instance BPH fraction corresponds to the Bound Protein High-molecular-weight fraction.
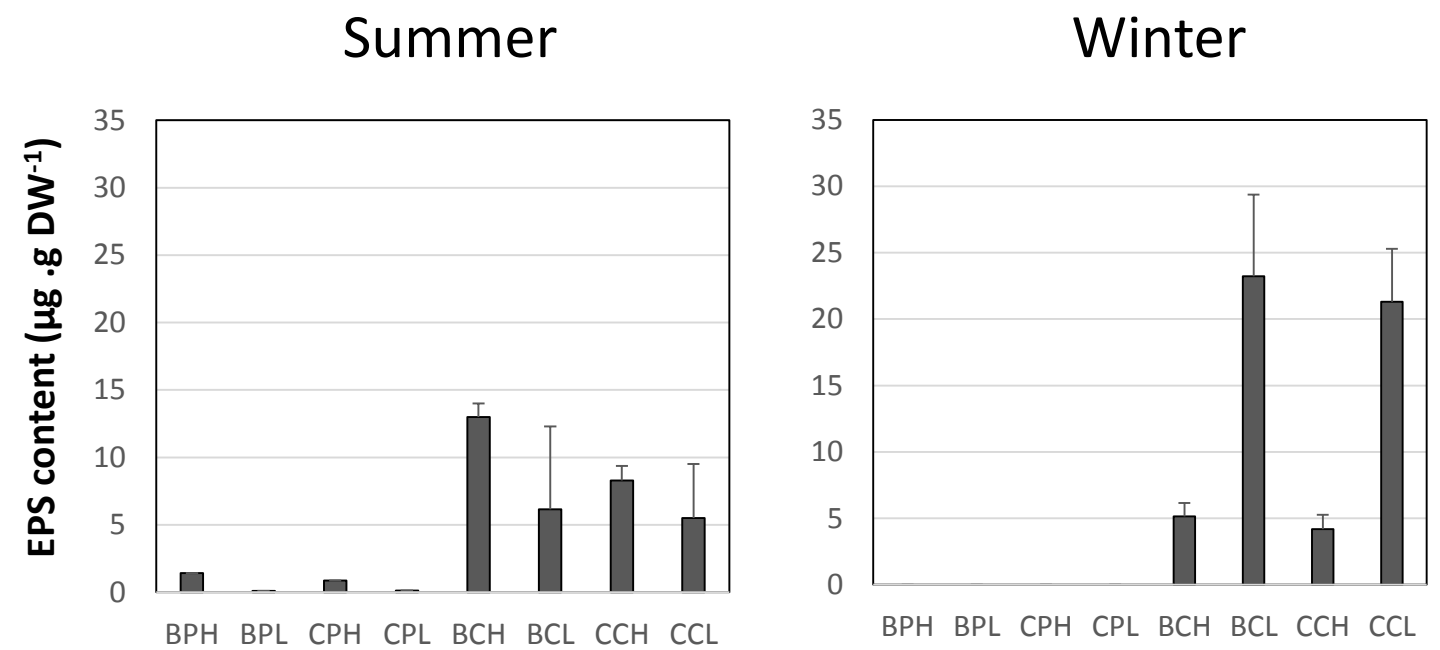
Fig 5: Variations in the four EPS carbohydrate fractions during the diurnal emersions at each sampling (presented chronologically within a day) for each season. A: colloidal High Molecular Weight (HMW in $\mu \mathrm{g}_{\mathrm{DW}}{ }^{-1}$ ); B: colloidal Low Molecular Weight (LMW in $\mu \mathrm{g} \mathrm{g}_{\mathrm{DW}}{ }^{-1}$ ); $\mathrm{C}$ : Bound High Molecular Weight (HMW in $\mu \mathrm{g} \mathrm{g}_{\mathrm{DW}}{ }^{-1}$ ); D: Bound Low Molecular Weight (LMW in $\left.\mu \mathrm{g}_{\mathrm{DW}}{ }^{-1}\right)$. Error bars are standard deviations between replicates. Gray squares represent winter samples, black circles represent summer samples. The Y-axis scale differs between fractions.

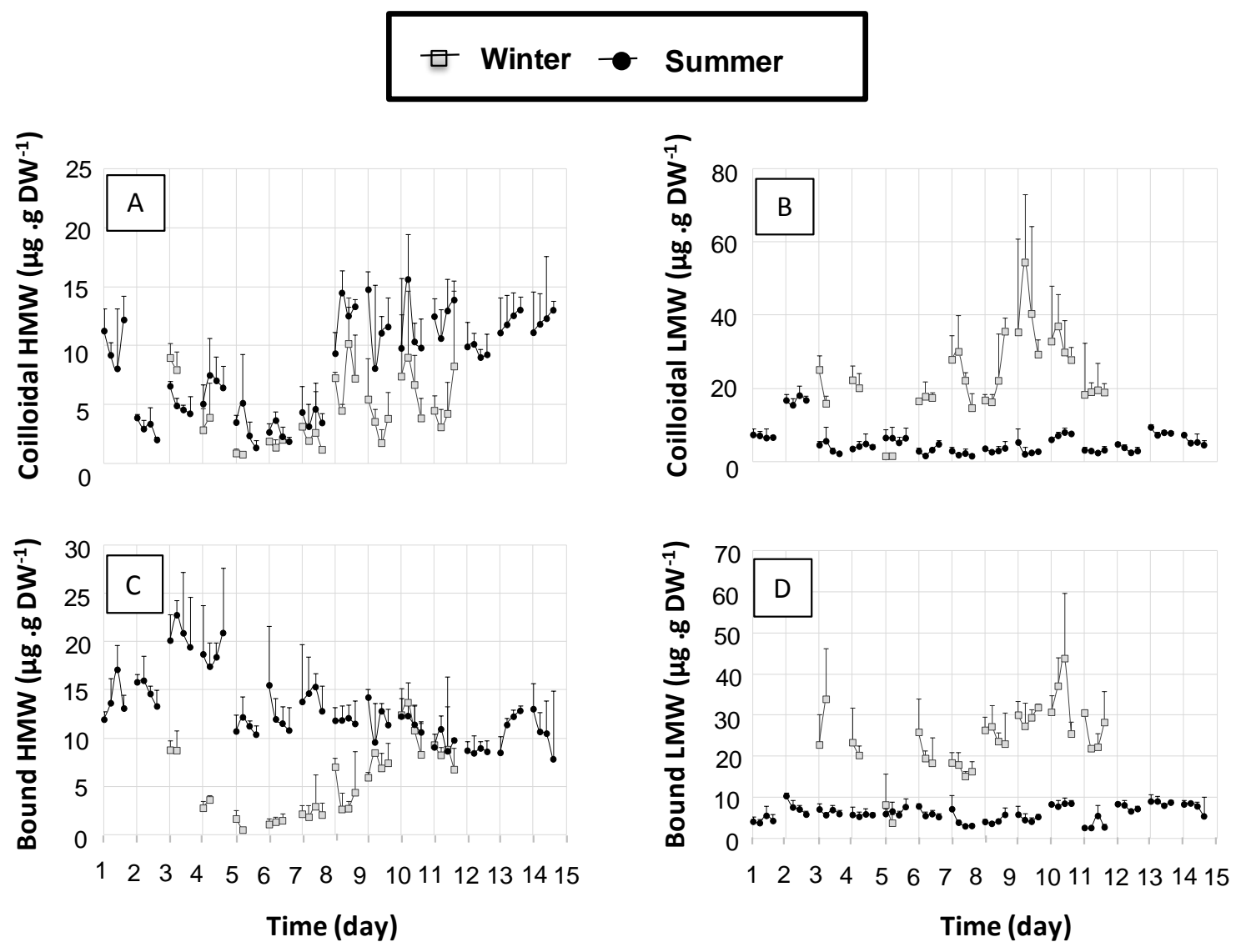


Fig. 6: Variations of EPS protein contents during diurnal emersions at each sampling (presented chronologically within a day) for each season. A: colloidal High Molecular Weight (HMW in $\mu \mathrm{g} \mathrm{g}_{\mathrm{DW}}{ }^{-1}$ ); B: bound High Molecular Weight (HMW in $\mu \mathrm{g} \mathrm{g}_{\mathrm{DW}}{ }^{-1}$ ). Error bars are standard deviations between replicates. Gray squares represent winter samples, black circles represent summer samples.

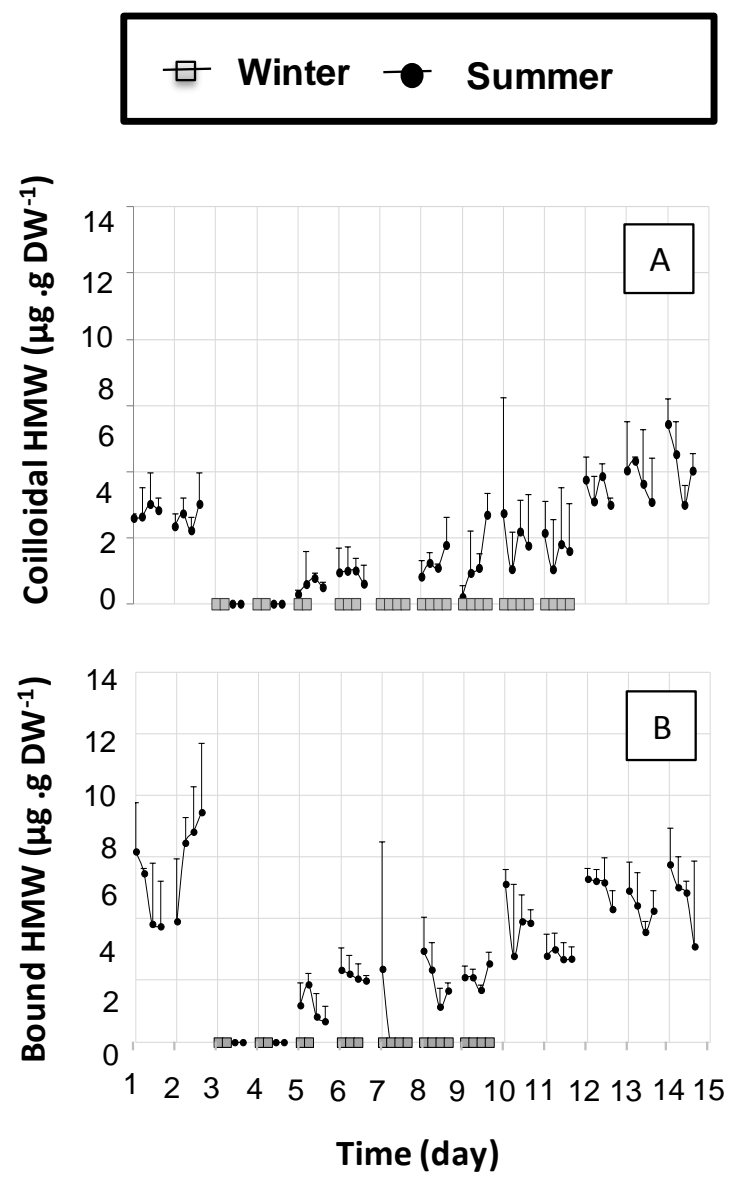


Table 1: Mantel Correlation statistics in February and July 2008 with Mantel Coefficients and Partial Mantel coefficients. Asterisks indicate significance: ns: not significant; *: $\mathrm{P}<0.05$; **: $\mathrm{P}<0.01$; ***: $\mathrm{P}<0.001$. Response variables are EPS with carbohydrate (Carb.) and protein (Prot.) contents in $\mu$ g.g DW ${ }^{-1}$ for Colloidal (C) and Bound (B) fraction, and High molecular weight $(\mathrm{H})$ and Low molecular weight $(\mathrm{L})$ fractions

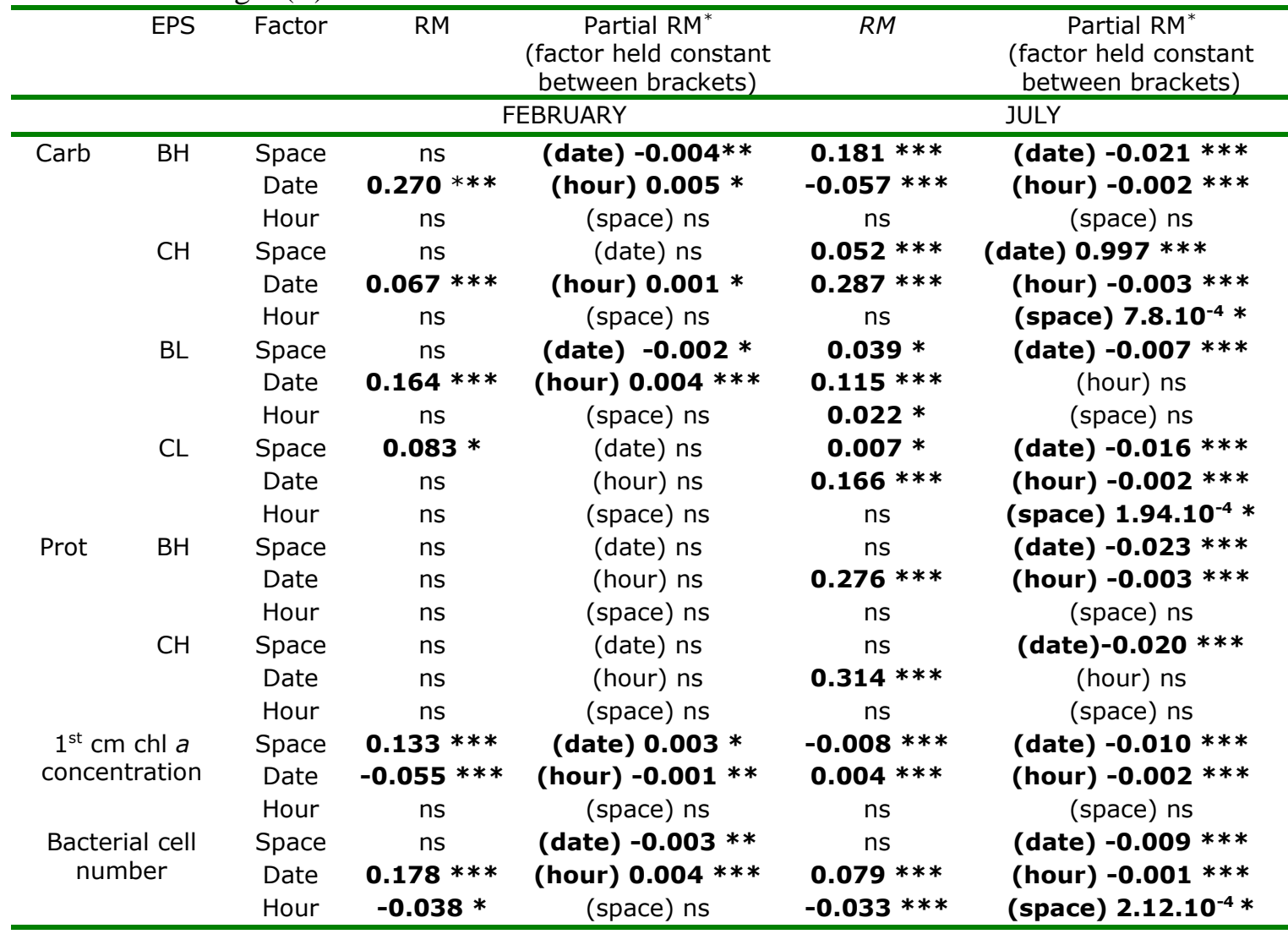


Table 2: Correlation Coefficients (r) between biotic variables (chl $a$ concentrations and bacterial abundance) and environmental parameters (salinity, water content, Irradiance, tidal amplitude) but also Peringia ulvae density. Coefficients are given for Winter (W) and summer (S) data, separately. Asterisks indicate significance *: $\mathrm{P}<0.05 ; * *$ : $\mathrm{P}<0.01$; ***: $\mathrm{P}<0.001$.

\begin{tabular}{|c|c|c|c|c|c|c|c|c|c|c|}
\hline Variable & Season & $\begin{array}{l}1^{\text {st }} \mathrm{cm} \\
\mathrm{Chl} \mathrm{a}\end{array}$ & $\begin{array}{l}\text { Bacteria } \\
\text { (n) }\end{array}$ & $\begin{array}{l}\text { Peringia } \\
\text { ulvae } \\
\text { (n) }\end{array}$ & $\begin{array}{l}1^{\text {st }} \mathrm{mm} \\
\mathrm{Chl} a\end{array}$ & S \%o & $\begin{array}{l}\text { Pore } \\
\text { water } \\
\text { content }\end{array}$ & $\mathrm{T}^{\circ} \mathrm{C}$ & Light & Tide \\
\hline \multirow{2}{*}{$\begin{array}{l}1^{\text {st }} \mathrm{cm} \mathrm{chl} \mathrm{a} \\
\text { concentration }\end{array}$} & W & / & $\mathrm{ns}$ & $\mathrm{ns}$ & ns & ns & $0.53^{* * *}$ & ns & ns & ns \\
\hline & $\mathrm{S}$ & / & $0.17^{*}$ & $-0.22^{* *}$ & ns & ns & $0.34^{* * *}$ & $0.16^{*}$ & ns & $-0.24^{* *}$ \\
\hline \multirow{2}{*}{$\begin{array}{l}\text { Bacterial } \\
\text { abundance }\end{array}$} & W & ns & / & ns & ns & ns & ns & ns & ns & ns \\
\hline & $\mathrm{S}$ & $0.31^{* * *}$ & / & $\mathrm{ns}$ & ns & ns & $0.47^{* * *}$ & ns & $-0.17^{*}$ & $-0.25^{* * *}$ \\
\hline \multirow{2}{*}{$\begin{array}{l}1^{\text {st }} \mathrm{mm} \text { chl a } \\
\text { concentration }\end{array}$} & w & ns & ns & $-0.31^{*}$ & / & ns & ns & $-0.43^{* *}$ & $-0.32^{*}$ & ns \\
\hline & $S$ & ns & ns & ns & / & $-0.22^{*}$ & ns & $-0.45^{* * *}$ & $-0.43^{* * *}$ & $-0.55^{* * *}$ \\
\hline
\end{tabular}


Table 3: Multiple Regression models and statistics explaining EPS contents in winter (W) and summer $(S)$ with EPS $=\sum A_{i} * Z_{i}+B$; coefficients $A_{i}$ for all explanatory factors $\left(Z_{i}\right)$ and $B$ the residual term. The regression coefficients $\mathrm{R}^{2}$ are given, when $\mathrm{P}<0.01$. Ranks of ecological factors in the regression model are displayed in brackets. Response variables are EPS with carbohydrate (Carb.) and protein (Prot.) contents in $\mu$ g.g DW ${ }^{-1}$ for Colloidal (C) and Bound (B) fraction, and High molecular weight $(\mathrm{H})$ and Low molecular weight $(\mathrm{L})$ fractions. Explanatory variables anre environmental parameters are (salinity S\%o, pore water content $\mathrm{W} \%$, light), $1^{\text {st }}$ $\mathrm{mm}$ chl $a$ concentration, $1^{\text {st }} \mathrm{cm}$ chl $a$ concentration, bacterial abundance and Peringia ulvae density (n).

\begin{tabular}{|c|c|c|c|c|c|c|c|c|c|c|c|c|}
\hline & \multicolumn{12}{|c|}{ Regression Coefficients (Ai) } \\
\hline & EPS & $\begin{array}{c}\text { Sea- } \\
\text { son }\end{array}$ & $\begin{array}{c}1^{\text {st }} \mathrm{cm} \mathrm{chl} \\
a\end{array}$ & $\begin{array}{l}\text { Bacteria } \\
\text { (n) }\end{array}$ & $\begin{array}{l}\text { Peringia } \\
\text { ulvae (n) }\end{array}$ & $\begin{array}{c}1^{\text {st }} \mathrm{mm} \\
\mathrm{chl} a\end{array}$ & S \%o & W (\%) & $\mathrm{T}^{\circ} \mathrm{C}$ & Light & $\mathrm{R}^{2}$ & (B) \\
\hline \multirow[t]{8}{*}{ Carb } & $\mathrm{BH}$ & W & l & I & $0.00049(2)$ & 1 & 1 & I & $0.38(3)$ & $0.00383(1)$ & 0.63 & -4.24 \\
\hline & & $\mathrm{S}$ & $0.116(2)$ & I & I & $0.300(4)$ & $\begin{array}{c}-0.697 \\
(1)\end{array}$ & $\begin{array}{c}-0.260 \\
(5)\end{array}$ & l & $0.0025(3)$ & 0.35 & 39.2 \\
\hline & $\mathrm{CH}$ & W & l & / & $0.00043(1)$ & $\begin{array}{c}0.134 \\
(2)\end{array}$ & l & l & / & / & 0.22 & -1.53 \\
\hline & & $\mathrm{S}$ & $-0.113(4)$ & $-1.11 .10^{-9}(5)$ & I & / & $0.826(1)$ & 0.790 & I & $-0.00342(2)$ & 0.32 & -53.3 \\
\hline & $\mathrm{BL}$ & W & I & $0.83 .10^{-9}(4)$ & $0.00154(1)$ & & I & $0.680(2)$ & & $0.0047(3)$ & 0.45 & -33.6 \\
\hline & & $\mathrm{S}$ & l & l & $0.00005(2)$ & l & I & $0.323(1)$ & -0.094 & I & 0.21 & -9.537 \\
\hline & $\mathrm{CL}$ & W & I & $2.05 .10^{-9}(2)$ & $0.0034(1)$ & I & I & I & $-0.86(3)$ & I & 0.41 & 4.86 \\
\hline & & $\mathrm{S}$ & I & I & $-0.00012(3)$ & I & I & $0.341(2)$ & I & -0.00308 & 0.26 & -5.60 \\
\hline \multirow[t]{2}{*}{ Prot } & $\mathrm{BH}$ & $S$ & I & I & I & I & 0.095 (3) & 0.123 & I & $-0.00108(1)$ & 0.25 & -7.22 \\
\hline & $\mathrm{CH}$ & $S$ & I & I & I & I & 0.129 (2) & 0.108 & I & $-0.00077(1)$ & 0.36 & -7.65 \\
\hline
\end{tabular}

